\title{
Parenteral high-dose ascorbate - A possible approach for the treatment of glioblastoma (Review)
}

\author{
OLGA RENNER $^{1}$, MARKUS BURKARD ${ }^{1}$, HOLGER MICHELS ${ }^{2}$, CLAUDIA VOLLBRACHT $^{2}$, \\ TOBIAS SINNBERG ${ }^{3,4}$ and SASCHA VENTURELLI ${ }^{1,5}$
}

\author{
${ }^{1}$ Department of Nutritional Biochemistry, University of Hohenheim, D-70599 Stuttgart; \\ ${ }^{2}$ Pascoe Pharmazeutische Praeparate GmbH, D-35394 Giessen; ${ }^{3}$ Department of Dermatology, University Hospital Tuebingen; \\ ${ }^{4}$ Cluster of Excellence iFIT (EXC 2180) Image Guided and Functionally Instructed Tumor Therapies, \\ University Hospital Tuebingen; ${ }^{5}$ Department of Vegetative and Clinical Physiology, \\ University Hospital of Tuebingen, D-72076 Tuebingen, Germany
}

Received February 22, 2021; Accepted April 5, 2021

DOI: $10.3892 /$ ijo.2021.5215

\begin{abstract}
For glioblastoma, the treatment with standard of care therapy comprising resection, radiation, and temozolomide results in overall survival of approximately 14-18 months after initial diagnosis. Even though several new therapy approaches are under investigation, it is difficult to achieve life prolongation and/or improvement of patient's quality of life. The aggressiveness and progression of glioblastoma is initially orchestrated by the biological complexity of its genetic phenotype and ability to respond to cancer therapy via changing its molecular patterns, thereby developing resistance. Recent clinical studies of pharmacological ascorbate have demonstrated its safety and potential efficacy in different cancer entities regarding patient's quality of life and prolongation of survival. In this review article, the actual glioblastoma treatment possibilities are summarized, the evidence for pharmacological
\end{abstract}

Correspondence to: Professor Sascha Venturelli, Department of Nutritional Biochemistry, University of Hohenheim, Garbenstr. 30, Bio Geb. I, Room 152, D-70599 Stuttgart, Germany

E-mail: sascha.venturelli@uni-hohenheim.de

Abbreviations: AMPK, adenosine monophosphate-activated protein kinase; ATP, adenosine triphosphate; AQPs, aquaporins; AA, ascorbic acid; ATM, ataxia telangiectasia mutated; BBB, blood-brain-barrier; CSF, blood-cerebral spinal fluid; bw, body weight; CNS, central nervous system; CAR, chimeric antigen receptor; $\mathrm{CP}$, choroid plexus; DHA, dehydroascorbate; EGFR, epidermal growth factor receptor; ECF, extracellular fluid; GLUT1, glucose transporter $1 ; \mathrm{H}_{2} \mathrm{O}_{2}$, hydrogen peroxide; HIFs, hypoxia inducible factors; i.v., intravenously; IDH, isocitrate dehydrogenase, GULO, L-gulono- $\gamma$-lactone-oxidase; mTOR, mammalian target of rapamycin; MGMT, $\mathrm{O}^{6}$-methylguanine-DNA methyl-transferase; SVCTI, sodium-dependent vitamin C transporter; SLC2A21, solute carrier family 2, facilitated glucose transporter, member 1; TERT, telomerase reverse transcriptase; TET, ten-eleven translocation; WHO, World Health Organization

Key words: glioma, glioblastoma, high-dose ascorbate, vitamin C, temozolomide, astrocytes ascorbate in glioblastoma treatment is examined and questions are posed to identify current gaps of knowledge regarding accessibility of ascorbate to the tumor area. Experiments with glioblastoma cell lines and tumor xenografts have demonstrated that high-dose ascorbate induces cytotoxicity and oxidative stress largely selectively in malignant cells compared to normal cells suggesting ascorbate as a potential therapeutic agent. Further investigations in larger cohorts and randomized placebo-controlled trials should be performed to confirm these findings as well as to improve delivery strategies to the brain, through the inherent barriers and ultimately to the malignant cells.

\section{Contents}

1. Introduction

2. Vitamin C

3. Vitamin $\mathrm{C}$ metabolism in normal CNS tissue

4. Entrance and distribution of vitamin $\mathrm{C}$ in the brain

5. Vitamin $\mathrm{C}$ in cancer

6. Trials evaluating pharmacological ascorbate in glioblastoma

7. Future directions and amplification of therapy effects

8. Conclusion

\section{Introduction}

Cancers of the central nervous system (CNS) affect the brain in $95 \%$ of cases and the remaining $5 \%$ are distributed among the meninges and spinal cord skin, cranial nerves, and spinal cord. Initially, tumors of CNS were classified based on their tissue and cell origin. Gliomas are of neuroectodermal origin, derived from the supporting glial cells within the CNS (1). They demonstrate a considerable variability in age of onset, grade of severity, histological features, and ability to progress as well as to metastasize (1-5).

According to the classification of CNS tumors published by the World Health Organization (WHO) in 2016, glioblastoma belong to the group of diffuse astrocytic and oligodendroglial 
tumors with aggressive clinical behavior corresponding to WHO grade IV comprising three subgroups: Primary glioblastoma, secondary glioblastoma with and without presence of isocitrate dehydrogenase (IDH) mutations, and the third one containing not otherwise specified glioblastoma tumors (1). Glioblastoma with IDH wild type represents $90 \%$ of the cases, which most frequently corresponds to the clinically defined primary or de novo glioblastoma that is predominantly found in patients aged over 55 years (6). Secondary glioblastoma with a history of prior lower-grade diffuse glioma mainly arises in younger patients and presents approximately $10 \%$ of the cases. The highest incidence with $\sim 65 \%$ is reported for individuals aged more than 65 years with the average annual age-adjusted rate of approximately 3 per 100,000 individuals per year (7). Glioblastomas are 1.58-fold more prevalent in males than in females. With a median survival time of 14 months, the diagnosis is very poor for patients with WHO grade IV tumors and only $5.6 \%$ of patients survive longer than five years post diagnosis (7-10).

The Consortium to Inform Molecular and Practical Approaches to CNS Tumor Taxonomy concluded that histologic grade II and III IDH wild-type diffuse astrocytic gliomas that contain a high-level of epidermal growth factor receptor (EGFR) amplification, a combination of whole chromosome 7 gain and whole chromosome 10 loss (+7/-10), or telomerase reverse transcriptase (TERT) promoter mutations, correspond to WHO grade IV and should be referred to as diffuse astrocytic glioma, IDH wild type, with molecular features of glioblastoma, WHO grade IV (11). It was also suggested that specific molecular signatures in subsets of IDH wild-type diffuse astrocytic gliomas are associated with better clinical outcomes and should not lead to a high-grade designation including those gliomas with other genetic alterations as individual drivers (11).

In order to accomplish early diagnosis and to develop personalized anti-cancer therapy, studies have focused on the identification of valid tumor markers that are easily accessible, can be simply analyzed, and provide accurate information regarding disease and severity (12). Epigenetic dysregulation of the ten-eleven translocation (TET) enzymes results in frequent epigenetic alterations in human glioblastoma including DNA hypermethylation and hypo-hydroxymethylation, as well as loss of histone acetylation (13).

Among others, the methylation status of the $\mathrm{O}^{6}$-methylguanine-DNA methyl-transferase (MGMT) gene promoter is such a molecular biomarker (14). Further genetic parameters, small non-coding RNAs, proteins, other small molecules, circulating tumor cells, and extracellular vesicles are possible candidates under investigation. These markers are quantifiable in tumor tissue or in body fluids such as blood, urine, or central spinal fluid (2). However, an established and generally accepted guideline to using them for diagnostic purposes is not available at the moment.

One of the current treatment options includes surgical resection aiming to remove as much contrast-enhancing tissue as possible without giving the patient a new functional deficit (15-17). Since most recurrences occur in close proximity to the primary tumor or in the tumor bed, percutaneous fractionated radiotherapy should also be performed (18). At present, the standard chemotherapeutic drug for glioblastoma is temozolomide (19-22).
Despite the aggressive therapy and research efforts, the prognosis for survival remains extremely poor and has not improved much over the last decades. The chemotherapeutic options are limited and restricted by poor distribution in the CNS due to the infiltrative nature, prominent angiogenesis, and vascularization of glioblastoma as well as acute systemic toxic effects and long-term toxicity in the CNS and bone marrow. The current research is dominated by checkpoint inhibitor trials, vaccine trials, and gene therapies (23). Of note, tumor-treating fields are electric fields that represent a non-invasive cancer treatment option that is applied locally, displaying good results in addition to standard of care therapy to improve the survival of newly diagnosed patients (24).

There has also been some success via the application of oncolytic viruses in the treatment of glioblastoma such as H1-parvovirus (25). The effects were caused in part by direct oncolysis but also by inducing the antitumoral immune response (25). Dendritic cell or peptide immunotherapy and chimeric antigen receptor (CAR) T-cell therapy are also under consideration (26). Even though there are some promising novel approaches, there remains a need to improve glioblastoma treatment options.

Interestingly, high vitamin $\mathrm{C}$ or ascorbate concentrations were shown to damage cancer cells by exhibiting pro-oxidative effects. On the other hand, high-dose ascorbate seems to be well tolerated by non-malignant cells (26-29). The aim of this review was to examine the current findings in regard to the therapeutic potential of pharmacological doses of vitamin $\mathrm{C}$ in the treatment of glioblastoma.

For this review, the literature research was performed using key words including 'glioblastoma', 'glioma', 'glioblastoma multiforme', 'vitamin C', 'ascorbate', 'ascorbic acid', and 'pharmacological' 'intravenous', 'IV', and 'high-dose' 'blood brain barrier', 'brain', 'cancer', 'vitamin C or ascorbate transporter', 'clinical trials', 'treatment', 'human' as well as 'ascorbate derivatives'. The terms were entered solely or in combination to find original articles and reviews on the homepage of the National Library of Medicine (PubMed.gov). The search was not restricted to publication date or other specifications, even though results from newly published studies were preferred over the older ones. However, in case of differences, both were cited in general. If results from clinical trials were published as original research, the details from human studies were verified using the following data sources https://clinicaltrials.gov, https://www.clinicaltrialsregister.eu/ctr-search/search, and https://www.who.int/clinical-trials-registry-platform.

\section{Vitamin C}

Vitamin C, also known as L-ascorbic acid (AA) or ascorbate, is an essential micronutrient and its deficiency is associated with several serious symptoms and ultimately death (30). In humans and most primates, vitamin $C$ needs to be supplied by the diet due to the lack of functional enzyme L-gulono- $\gamma$-lactone oxidase (GULO), which catalyzes the last step of AA biosynthesis (31). In fluids, vitamin $\mathrm{C}$ occurs in two major forms as ascorbate $(90 \%)$ or in its oxidized form dehydroascorbate (DHA). Under physiological conditions, the amount of DHA in plasma is estimated as $<1-2 \%$ relative to plasma ascorbate levels (32). The recommended daily dose of vitamin $\mathrm{C}$ varies 
between 75 and $100 \mathrm{mg}$ resulting in physiological plasma levels of 50-100 $\mu \mathrm{mol} / 1(33,34)$. However, there are major discrepancies regarding recommendations for dietary vitamin $\mathrm{C}$ intake depending on individual physiological and pathophysiological conditions (35).

With ingested amounts found in foods, vitamin C plasma concentrations usually do not exceed $100 \mu \mathrm{mol} / \mathrm{l}$ (32). Even after oral supplementation, ascorbate plasma concentrations stay below $250 \mu \mathrm{mol} / \mathrm{l}$ and often lower than $150 \mu \mathrm{mol} / \mathrm{l}(32,36)$. By contrast, after intravenous ascorbate injection (i.v.), pharmacologic plasma ascorbate concentrations of $26.2+/-4.9 \mathrm{mmol} / \mathrm{l}$ are safely achieved (37). Serious side effects were only reported for patients with pre-existing renal insufficiency or glucose 6-phosphate dehydrogenase deficiency, both known to be predisposed to vitamin C toxicity (38). Besides tissue accumulation and renal reabsorption, the major determinant of plasma concentration of orally ingested vitamin $\mathrm{C}$ is the saturable capacity of the gut. Parenteral ascorbate bypasses the intestinal absorption mechanisms that are responsible for this limitation and therefore allows the use of ascorbate as a pharmacological agent. For vitamin C, a linear relationship between dose and $\mathrm{C}_{\max }$ can be observed up to $70 \mathrm{~g} / \mathrm{m}^{2}$ in humans [approximately $112 \mathrm{~g}$ in females (body surface: $1.60 \mathrm{~m}^{2}$ ) and $133 \mathrm{~g}$ in males (body surface: $1.90 \mathrm{~m}^{2}$ )] as complied from pharmacokinetic studies, while higher doses do not translate into higher plasma $\mathrm{C}_{\max }$ levels $(39,40)$.

There is growing evidence that patients with cancer have lower vitamin C plasma levels than healthy controls (41-46) and a large proportion of them exhibit hypovitaminosis for vitamin C or manifest deficiency (47-53). Severity of the disease also appears to correlate with the vitamin $\mathrm{C}$ status and higher stages of cancers seem to be associated with lower vitamin C levels $(52,54,55)$. Mayland et al showed that patients with low vitamin $\mathrm{C}$ plasma levels have a significantly worse prognosis than patients with sufficient plasma levels (48). Although it is suspected that vitamin $\mathrm{C}$ blood levels are low in patients with glioblastoma, no data according vitamin $\mathrm{C}$ deficiency, symptoms, and disease progress are currently available for this tumor entity.

\section{Vitamin C metabolism in normal CNS tissue}

Ascorbate is required for homeostasis and proper functioning of the central nervous system. The brain consumes a large portion of glucose $(\sim 25 \%)$ and oxygen $(\sim 20 \%)$, which implies rapid metabolism with increased free radical production. Being an organ that metabolizes oxygen with relatively weak protective antioxidant mechanisms, the brain is particularly susceptible to oxidative stress (56). It therefore depends on high levels of antioxidants to maintain redox balance. Accordingly, ascorbate is the physiologically most abundant antioxidant present in brain tissue.

As a water soluble agent, vitamin $\mathrm{C}$ is absorbed from the small intestine and then distributed from blood throughout the extracellular space (32). Vitamin C is accumulated in tissues against a concentration gradient. The concentrations of vitamin $C$ in tissues are frequently higher (up to $4,000 \mu \mathrm{mol} / \mathrm{l}$ ) than in fluids (up to $300 \mu \mathrm{mol} / \mathrm{l}$ ) and may simply serve as a reservoir or have other unknown functions $(32,36,57)$. It should be noted that for many human tissues accurate vitamin $\mathrm{C}$ concentrations are not known for physiological nor pathophysiological conditions. The total average concentration of vitamin $\mathrm{C}$ in the brain is lower in comparison to the adrenal gland, lens, or liver. Within the brain, the highest concentration was observed in the pituitary gland and accumulation in neurons with $10 \mathrm{mmol} / \mathrm{l}$ was markedly higher than in the cerebral spinal fluid or glial cells with only $1 \mathrm{mmol} / \mathrm{l}$ suggesting an important role in the maintenance of neuronal integrity $(32,58-61)$.

\section{Entrance and distribution of vitamin $\mathrm{C}$ in the brain}

As a hydrophilic molecule, vitamin C enters the CNS from the blood-brain-barrier (BBB) or from the blood-cerebral spinal fluid (CSF) barrier formed by epithelial cells of the choroid plexus (CP) (Fig. 1) $(62,63)$. Vitamin C initially accumulates in $\mathrm{CP}$ cells and then passes through the CSF into the brain (63). This observation confirms the data from knockout mice analysis and cell models (64-68).

The incorporation of ascorbate in the cells is mediated via specific transporters termed sodium-dependent vitamin C transporter (SVCT) 1 and 2 (69-72). SVCT2 is the absorptive vitamin $\mathrm{C}$ transporter in the brain (69). DHA is translocated via the solute carrier family 2 , facilitated glucose transporter, member 1 [SLC2A1 or glucose transporter 1 (GLUT1)] (73). Due to the lack of SVCT2 in cerebrovascular endothelial cells, transport via BBB occurs as DHA via GLUT1 (74). As DHA concentration is low in blood, the role and influence of this transport route into the extracellular space regarding the maintenance of the ascorbate concentration in the brain seems to be insignificant under physiological conditions.

Ascorbate enters CNS through SVCT2 present in choroid plexus cells on the basal side $(75,76)$ of the $\mathrm{CP}$ and also probably through GLUT1 $(69,77)$ and is then distributed into ventricular space from which it penetrates across ependyma and pia mater deeply into the brain (78). The concentration of ascorbate is thereupon balanced between cerebrospinal fluid and the extracellular fluid (ECF) by diffusion through ependymal cells.

SVCT2 is not expressed in astrocytes under physiological conditions but these brain cells play an important role in the regeneration of DHA into ascorbate. It is postulated that astrocytes incorporate DHA through GLUT1 $(79,80)$ and then convert DHA into ascorbate due to the 4-fold higher intracellular glutathione levels compared to neurons (81). After the conversion of DHA to ascorbate within astrocytes, it is released from astrocytes and extracellular ascorbate is capable of entering neurons via SVCT2 again (82). This circuit describes the bystander effect including vitamin C recycling between astrocytes and neurons, in which neurons are the 'activated cells' inducing oxidation of ascorbate to DHA which is subsequently absorbed by the astrocytes as 'bystander cells' $(63,83)$.

This ascorbate recycling as an interaction between astrocytes and neurons is crucial for the maintenance of normal brain ascorbate levels required for different functions inside the CNS such as catecholamine biosynthesis (84), peptide amidation (85), myelin formation (86), enhancement of synaptic activity (87), protection against glutamate toxicity (88), and modulation of precursor cell proliferation and differentiation $(63,89,90)$. Taken together, vitamin $\mathrm{C}$ is 


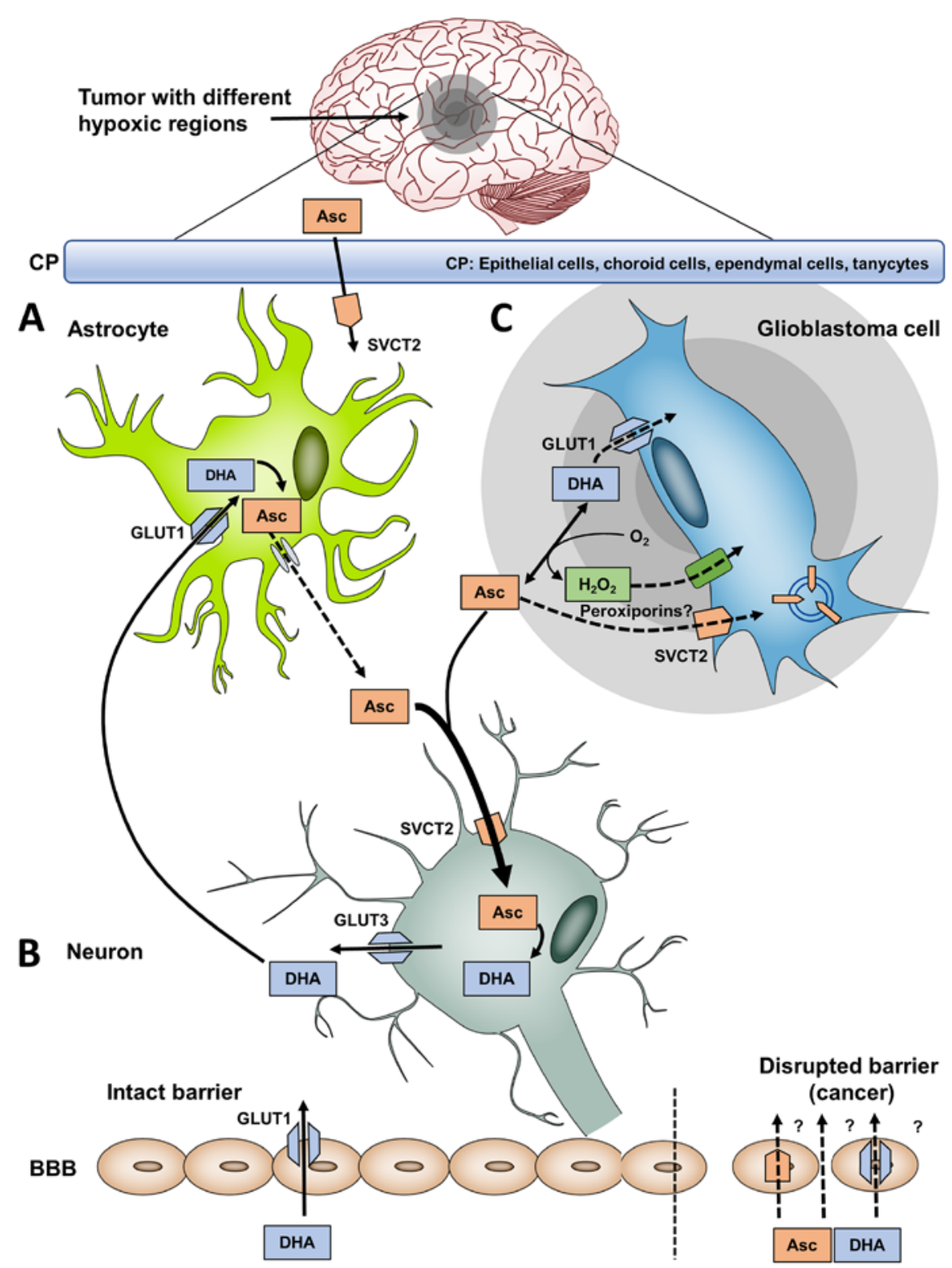

Figure 1. Schematic representation of vitamin C uptake and compartmentalization in the brain with resident glioblastoma. Vitamin C (Ascorbate=Asc) enters the central nervous system (CNS) by two routes, via blood-brain-barrier (BBB, lower layer of cells) and blood-central-spinal fluid-barrier (blue horizontal bar at the top, above the cell images), BBB and choroid plexus (CP) represent a tightly regulated barrier for precise substance entrance into the brain. Vitamin $\mathrm{C}$ translocates from the blood through BBB in its oxidized form as dehydroascorbate (DHA) using glucose transporter 1 (GLUT1). CP is formed by epithelial cells, choroid cells, and ependymal cells or tanycytes as mentioned within the blue bar. The entry of vitamin $\mathrm{C}$ in its reduced form is mediated by sodium-dependent vitamin C transporter 2 (SVCT2) expressed within the choroid cells. Under pathophysiological conditions such as glioblastoma, the barrier seems to be disrupted. Thus, the vitamin $\mathrm{C}$ transporters expression and their functionality may be altered as the total amount of vitamin $\mathrm{C}$ entering the nervous system is changed. Dashed lines with arrows represent processes, which are still unknown or the hierarchy of three members is not finally understood. Continuous lines with arrows represent known routes according to the current state of knowledge. (A) The major substrate for astrocytes is DHA, which enters into the cell via GLUT1. After regeneration, vitamin C leaves astrocytes and is either usable extracellularly or for neurons. (B) Once inside CNS, vitamin C is consumed by neurons and utilized to DHA. DHA is then released by neurons via GLUT3 into the extracellular space. (C) The expression patterns and the functionality of vitamin C transporters (SVTC2 and GLUT1) as well as their role in the cellular uptake of vitamin C are still not fully clarified. Furthermore, vitamin $\mathrm{C}$ is able to produce hydrogen peroxide $\left(\mathrm{H}_{2} \mathrm{O}_{2}\right)$ within the extracellular space. Peroxiporins, as a subtype of aquaporins, are speculated to be the possible channels for $\mathrm{H}_{2} \mathrm{O}_{2}$ entrance into the cancer cell. Adapted from $(28,63,73,77,176,179,180,189)$.

found in higher concentrations in CSF and brain parenchyma (200-400 $\mu \mathrm{mol} / \mathrm{l})$ than in plasma $(30-60 \mu \mathrm{mol} / \mathrm{l})(91,92)$.

\section{Vitamin $\mathrm{C}$ in cancer}

Since Cameron and Pauling demonstrated that ascorbate-treated terminal cancer patients experienced a 4.2 -fold increase in the mean survival time compared to untreated controls (93), the role of vitamin $\mathrm{C}$ in tumorigenesis and anti-cancer treatment has become the object of investigations and still not finally clarified. Twenty years later, the pharmacokinetics of ascorbate were described by Levine et al (36).

Ascorbate was an early unconventional and inexpensive therapy for the treatment of cancer with an excellent safety profile and surprising clinical efficacy (93). However, as two clinical trials with oral ascorbate failed to reproduce these effects, ascorbate was not used any more in the conventional oncologic therapy and shifted to the field of complementary 
and alternative medicine $(94,95)$. Interestingly, previous studies resulted in the re-examination of ascorbate treatment and it became clear that only parenteral application of ascorbate yielded millimolar plasma levels with high efficacy against tumor progression (96-99). As the existing evidences are preliminary, there is a number of fundamental questions around best clinical practice, frequency of therapy, dosage, duration as well as treatment guidelines for each tumor entity and grade (100-102).

The chemistry of ascorbate defines its biological activity in terms of its function as an anti-oxidant as well as a pro-oxidant. It initiates selective toxicity in cancer cells (26) but not in normal cells and enhances cytotoxic effects in combination with radiotherapy and/or chemotherapy (103). The prodrug effect of pharmacological ascorbate includes its ability to form and deliver extracellular hydrogen peroxide $\left(\mathrm{H}_{2} \mathrm{O}_{2}\right)$ to tissue (27). $\mathrm{H}_{2} \mathrm{O}_{2}$ crosses cell membranes via peroxiporins (104-106). The selective toxicity of ascorbate depends on an altered $\mathrm{H}_{2} \mathrm{O}_{2}$ metabolism in cancer compared to non-malignant cells.

The mechanism of cytotoxicity of pharmacological vitamin $\mathrm{C}$ is not only associated with high levels of extracellular $\mathrm{H}_{2} \mathrm{O}_{2}$ (26) but also involves labile iron pools. These catalyze the oxidation of ascorbate to produce $\mathrm{H}_{2} \mathrm{O}_{2}$ thereby generating the hydroxyl radical from $\mathrm{H}_{2} \mathrm{O}_{2}$ via the Fenton reaction and causing oxidative damage to cellular lipids, proteins, and DNA (Fig. 2) (28). This effect is well described for neuroblastoma (107). Therefore, there are two mechanisms, which contribute to the selective toxicity of ascorbate in cancers: First, a reduced capacity to remove $\mathrm{H}_{2} \mathrm{O}_{2}$ and second, superoxide as well as $\mathrm{H}_{2} \mathrm{O}_{2}$-induced disruption of the iron metabolism with increased levels of redox active iron $(28,103,108-111)$. Interestingly, the addition of extracellular catalase in vitro eliminates the anti-tumoral effects of high-dose ascorbate almost completely and therefore formation of extracellular $\mathrm{H}_{2} \mathrm{O}_{2}(112,113)$ seems to be a major contributor to the anti-tumoral effects. The intracellular reactive oxygen species formation appears to also affect cancer cells containing large amounts of labile iron (28). Furthermore, elevated iron levels identified in cancer cells activate iron-dependent proteins that promote adaptation to hypoxia and stimulate cell proliferation $(114,115)$. The question whether ascorbate or DHA is the most effective vitamin species was elucidated in cell models $(28,116,117)$ and showed that GLUT-mediated DHA uptake does not play a major role in ascorbate toxicity. This is biologically plausible, because DHA cannot form toxic $\mathrm{H}_{2} \mathrm{O}_{2}$, extracellularly.

The concentration of $\mathrm{H}_{2} \mathrm{O}_{2}$ seems to determine the expression and activity of the antioxidant enzymes that remove $\mathrm{H}_{2} \mathrm{O}_{2}$, including catalase, glutathione peroxidase, and peroxiredoxins, whereas catalase levels were shown to be lower in malignant-transformed cells compared to untransformed ones $(111,118,119)$.

The metabolism of tumor cells differs from that of normal cells with a shift from energy-producing pathways to those generating macromolecules necessary for proliferation and tumor growth, known as the Warburg effect. This is evident together with hypoxia, a characteristic sign of solid tumors $(120,121)$. Several mechanisms are involved in the development of hypoxia causing significant heterogeneity in the tissue oxygen levels in tumors (122). Adapting to an oxygen-depleted microenvironment, tumors upregulate hypoxia inducible factors (HIFs) and shift to an anaerobic energy production (123). Previous studies in patients with brain cancer have already described an increase of the expression of HIF-1 and GLUT-1 correlating to the malignancy grade (from grades II to IV) (124-126). Previous findings on glioblastoma cells showed a novel epigenetic mechanism underlying modulation of HIF-1 transcriptional activity that enable cancer cells to rapidly respond to hypoxic stress (127). A hypoxia-induced negative feedback mechanism that maintains high activity of HIF-1 and cell mobility in human glioblastoma cells has been suggested $(112,127)$. Previous findings on breast cancer tissue showed that higher vitamin $\mathrm{C}$ concentrations in tumor tissue correlate with lower HIF-1 activity and increased disease-free and disease-specific survival (128).

Importantly, ascorbate-dependent restoration seems to play a role in cancer epigenetics. Given the fact that ectopic overexpression of TET2 regulates neural differentiation in glioblastoma cell lines and impairs tumor growth (13), it would be meaningful to assess the effects of vitamin $\mathrm{C}$ in this process (129). Results of a recent randomized clinical trial focusing on intravenous vitamin $\mathrm{C}$, adjuvant to decitabine, showed activation of TET2 in leukemic cells and a significant improvement in overall survival in elderly patients with acute myeloid leukemia (12).

Alteration in the differentiation potential of cancer stem cells and blocking metastasis is also important (130). Experiments with different glioblastoma cells showed that changes of mitochondrial oxidative and intracellular iron metabolism in combination with pharmacological ascorbate treatment induces cancer cell selective toxicity (28). Moreover, daily pharmacologic ascorbate treatment significantly decreased growth rates of gastric, ovarian, and pancreatic cancers as well as glioblastoma established in mice $(99,131-134)$. There are numerous studies demonstrating the usage of pharmacological ascorbate as an adjuvant to enhance radiation or chemotherapy responses (113,131,135-138). Millimolar concentrations of ascorbate were able to induce pro-oxidative effects in the interstitial fluid of the tumor cells mainly caused by extracellular $\mathrm{H}_{2} \mathrm{O}_{2}$ formation resulting in DNA damage in tumor cells and cellular adenosine triphosphate (ATP) depletion. Furthermore, it was described that the ataxia telangiectasia-mutated (ATM)/adenosine monophosphate-activated protein kinase (AMPK) pathway was activated and the mammalian target of rapamycin (mTOR) was inhibited in ovarian cancer cells (99). The combination of parenteral ascorbate with the conventional chemotherapeutics carboplatin and paclitaxel synergistically inhibited the growth of ovarian cancer in mouse models and reduced chemotherapy-associated toxicity in patients with ovarian cancer by ascorbate treatment (99).

In accordance with the data from in vitro and rodent models, in which pharmacologic concentrations of ascorbate act as a pro-oxidant locally on cancer cells and as an antioxidant preventing normal tissue from chemotherapy or radiation injury, ascorbate was applied intravenously to humans in clinical trials. It is generally challenging to transfer in vitro results to the in vivo situation, especially regarding glioblastoma treatment, since high-dose ascorbate has to pass the BBB and other tumor-related conditions. The interaction of 


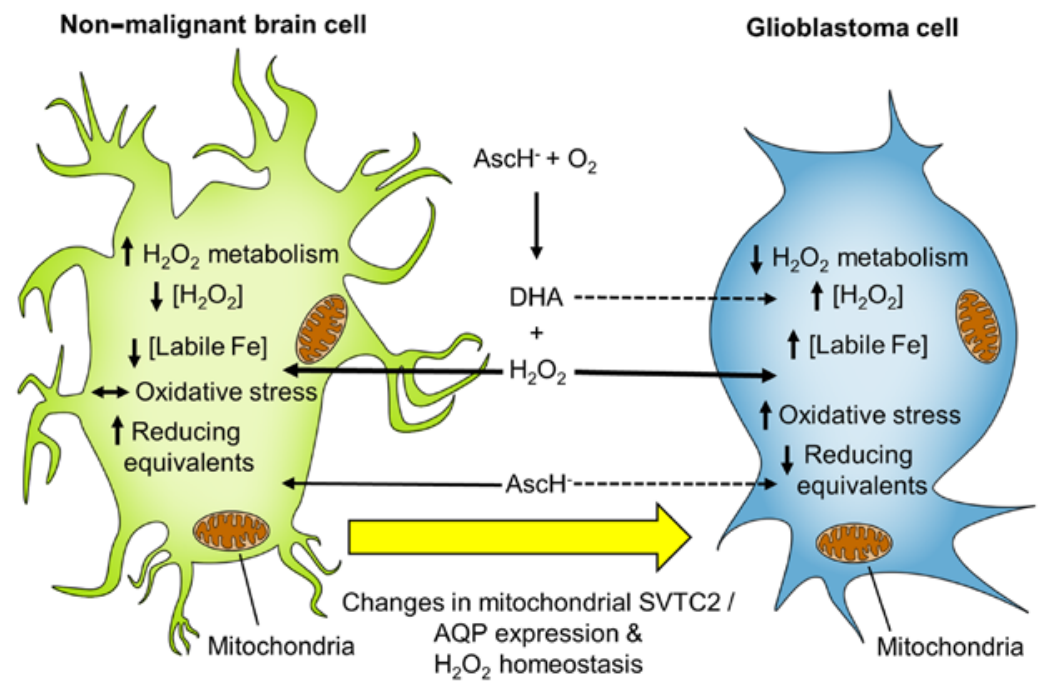

Figure 2. Differences between non-malignant and glioblastoma brain cells in hydrogen peroxide $\left(\mathrm{H}_{2} \mathrm{O}_{2}\right)$ metabolism and redox-active iron metabolism (Fe) induced by pharmacological ascorbate $\left(\mathrm{AscH}^{-}\right)$. The selective toxicity of pharmacological ascorbate to cancer cells is mainly an $\mathrm{H}_{2} \mathrm{O}_{2}$-mediated mechanism. Extracellular oxidation of ascorbate produces $\mathrm{H}_{2} \mathrm{O}_{2}$, which channels into the cell. In non-malignant cells, vitamin $\mathrm{C}$ is non-toxic due to a high capacity to metabolize $\mathrm{H}_{2} \mathrm{O}_{2}$ in relation to well-regulated iron metabolism. These properties limit the levels of redox-active, labile iron, and the associated production of oxidizing free radicals. The absence of ascorbate-mediated oxidative distress allows the reduction of ascorbate capabilities as an antioxidant. By contrast, decreased capacity of cancer cells to remove $\mathrm{H}_{2} \mathrm{O}_{2}$ as well as cancer-cell-specific disruptions in iron metabolism result in increased levels of labile iron and lead to significant oxidative stress as well as to decreased amounts of reducing equivalents. Both tumor-determined cellular alterations and chemo-radiation-induced free radical production cause an increased susceptibility of glioblastoma cells to pharmacological ascorbate compared to non-malignant cells. These changes include vitamin $\mathrm{C}$, its metabolites, and $\mathrm{H}_{2} \mathrm{O}_{2}$ transport capabilities through the cellular and mitochondrial membrane, via sodium-dependent vitamin C transporter 2 (SVCT2) and peroxiporins as well as their altered metabolism. Dashed lines represent mechanisms, whose role in the overall vitamin $\mathrm{C}$ actions is not finally clarified. Continuous lines with arrows represent known routes according to the current state of knowledge. Adapted from $(27,28,103,180)$.

neurons and astrocytes is also crucial, e.g., the regeneration of ascorbate from DHA. In addition, a considerable number of clinical studies showed that cancer patients treated with intravenous ascorbate in addition to chemotherapy or radiation demonstrated a significantly ameliorated performance whereas therapy-induced side effects were limited, resulting in improved quality of life $(37,99,139,140)$.

Nauman et al performed a systematic review of intravenous ascorbate in clinical cancer studies. A total of 23 clinical trials (all of phase I/II) were examined, therefrom 11 trials were ongoing and 11 studies aimed to evaluate low-dose intravenous ascorbate with arsenic oxide (141). The included clinical trials from different cancer entities were aimed to evaluate the effects of intravenous ascorbate.

Overall, it was evident that ascorbate was safe in almost all patient populations and exhibited potential to reduce toxicities of other cancer treatment regimens. The chemotherapeutic potential of vitamin $\mathrm{C}$ requires high concentrations, which can only be achieved intravenously. However, the $\mathrm{IC}_{50}$ values of vitamin $\mathrm{C}$ against tumor cells determined in vitro vary greatly depending on the tumor cell line employed. No conclusive clinical data are yet available regarding the necessary intravenous amount. Most studies use a frequency of at least twice weekly and doses of approximately $1 \mathrm{~g}$ per kg body weight (bw) with promising results in solid tumors $(96,97,141)$. One randomized controlled clinical trial observed benefits with smaller amounts of $60-80 \mathrm{mg} / \mathrm{kg}$ bw in patients with acute myeloid leukemia (12). However, a small trial with doses lower than $1 \mathrm{~g} / \mathrm{kg}$ seemed to be therapeutically ineffective (142). Considering different cancer entities, applied chemotherapeutic agents and regimens of radiation, the goal of most investigations was to achieve a plasma concentration of approximately
$22 \mathrm{mmol} / \mathrm{l}$ as described by Riordan et al (49). The therapeutic concentration and frequency in high-dose ascorbate studies differed from 50 to $100 \mathrm{~g}$ and higher per day as infusion, twice to three times weekly and the duration of treatment depended on study design (141-145).

\section{Trials evaluating pharmacological ascorbate in glioblastoma}

In addition to an overview on the clinical use of vitamin $\mathrm{C}$ and its pharmacokinetics with an emphasis on bioavailability in the CNS, this review focused also on the study situation on high-dose intravenous ascorbate in oncology with particular relevance to glioblastoma. Using the terms 'glioblastoma', 'glioma', and 'glioblastoma multiforme' as well as 'vitamin C', 'ascorbate', 'ascorbic acid', and 'pharmacological' 'intravenous', 'IV', and 'high-dose' in the following data sources https://clinicaltrials.gov, https://www. clinicaltrialsregister.eu/ctr-search/search, https://www.who. int/clinical-trials-registry-platform, and https://www.ncbi for clinical trials, a total of 11 studies were identified (Table I). Therefrom, intravenous ascorbate was found to be applied in four phase I and II trials.

In the Phase I trial NCT01752491 (active, not recruiting), the safety of high-dose ascorbate was tested in combination with chemotherapy and temozolomide according to Stupp et al (8) in a total of 13 study subjects. Only patients above 18 years of age were included in that study. Thereby, dose escalation (15-125 g) was performed for the radiation and for the adjuvant periods for each subsequent study subject. Escalating weekly doses of ascorbate (up to $125 \mathrm{~g}$ ) to target a serum level of $350 \mathrm{mg} / \mathrm{dl}(20 \mathrm{mM})$ showed that application 


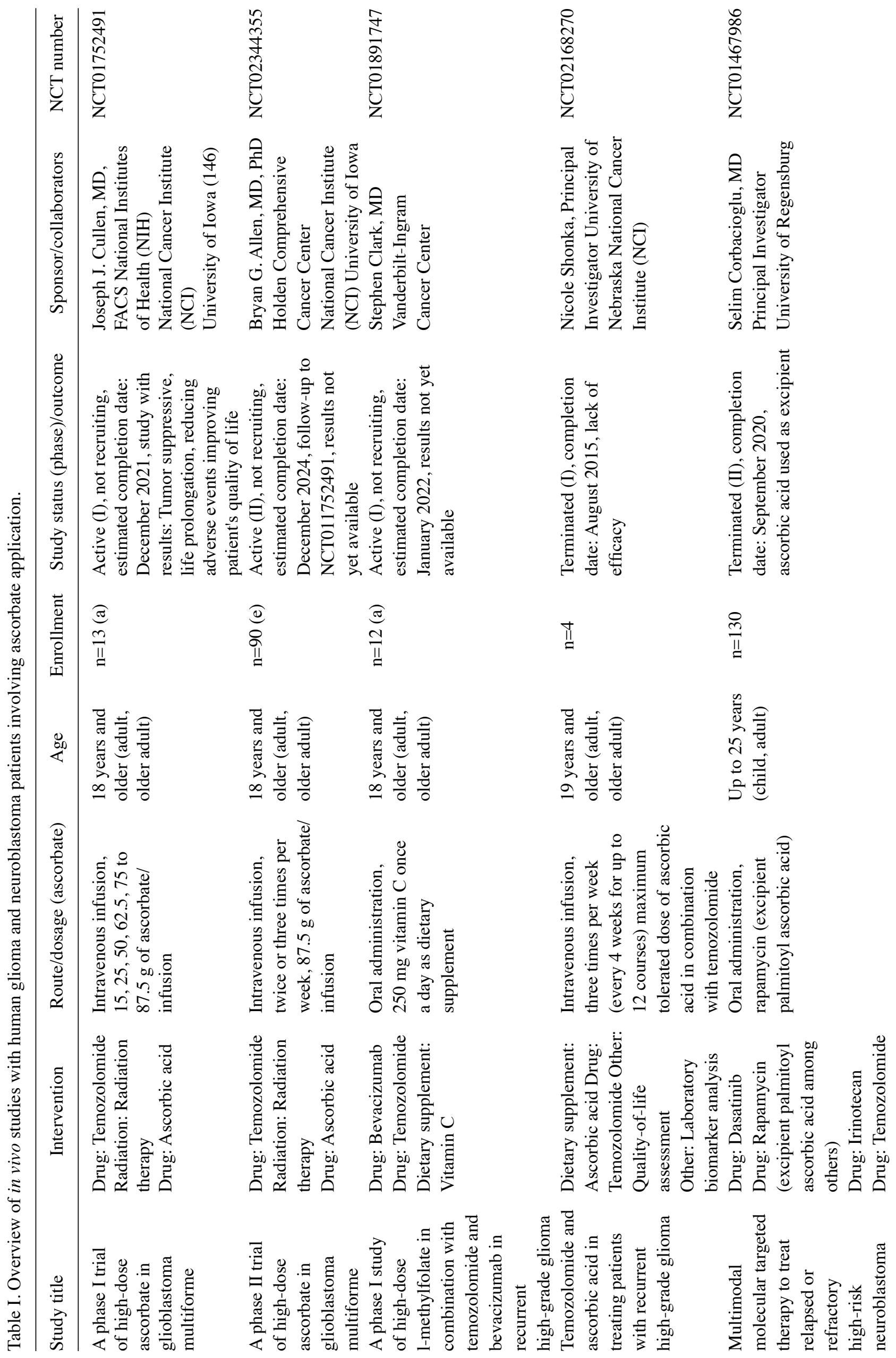




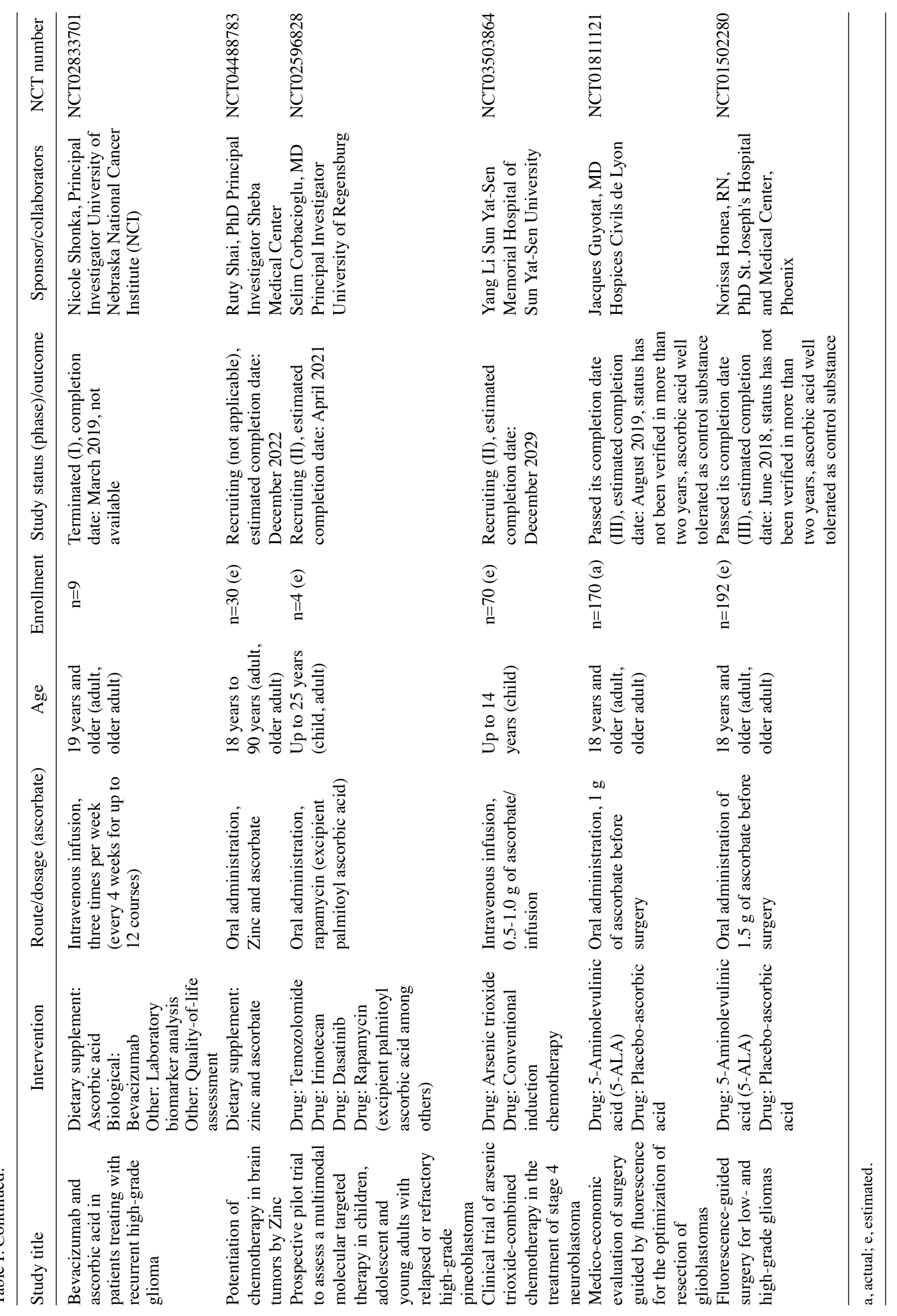


of $87.5 \mathrm{~g}$ consistently resulted in plasma ascorbate concentrations $\geq 20 \mathrm{mM}(28,146)$. The absence of ascorbate-mediated serious adverse events in neither the radiation nor adjuvant phase enabled all subjects to maintain their performance status throughout treatment. Overall, pharmacological ascorbate was well tolerated and adverse events were restricted to dry mouth, fatigue, nausea, vomiting, infection, leukopenia, and neutropenia (rendering from grade 1-3, in total). The median overall survival was 18.3 months $(146,147)$ compared to the historical median of 14 months according to Stupp et al (8). Therefore, it was found that subjects with unmethylated MGMT promoter as well as IDH wild type had longer overall and progression-free survival compared to other study participants. This treatment protocol for pharmacological ascorbate was applied for one woman with glioblastoma in New Zealand (147). She lived over four years from glioblastoma diagnosis largely experiencing good quality of life.

In the ongoing open-labeled, single group assigned Phase II trial NCT02344355 (active, not recruiting), intravenous infusions of $87.5 \mathrm{~g}$ of ascorbate are administered three times weekly during and after radiation. Additionally, ascorbate was planned to be administered twice weekly through the end of cycle six of temozolomide. The radiation and temozolomide treatments are based on the previously conducted phase I study NCT01752491 $(8,28,146)$. According to this protocol, the overall and progression-free survival, the adverse event frequency as well as the quality of life were to be evaluated in a cohort of 90 glioblastoma patients. In extension of the data from Schoenfeld et al (28) and Allen et al (146), Cushing et al (148) established an application using magnetic resonance imaging in humans to visualize and measure changes in redox-active iron areas due to pharmacological ascorbate. In a small sample-sized study, 15 subjects from NCT02344355 underwent optical imaging procedures during application of high-dose ascorbate in addition to standard of care treatment. Five glioblastoma patients without ascorbate treatment were invited to participate as an active comparison group in the study. Although without statistical significance, due to the small number of subjects included in the study, the article described a method that can be employed to monitor in vivo changes in redox-active iron metabolism caused by the direct manipulation of endogenous redox state of iron in cancer subjects, which is in line with previous observations $(28,134,148)$.

There are two more dose-escalation studies that investigated intravenous ascorbate treatments in patients with recurrent high-grade glioma (NCT02168270, NCT02833701), both performed at the University of Nebraska. In the Phase I study, no. NCT02833701, the role of bevacizumab and ascorbic acid was examined in nine patients with recurrent high-grade glioma. In the Phase I study, no. NCT02168270, temozolomide and ascorbic acid were tested in four participants. In both trials, patients received ascorbate intravenously over 90-120 min three times per week in addition to bevacizumab or temozolomide, respectively. Treatment was repeated every 28 days for up to 12 courses in the absence of disease progression or unacceptable toxicity for each study. The primary outcome measurements intended the determination of the maximum-tolerated dose of intravenous ascorbate given three times weekly in combination with temozolomide or bevacizumab and the evaluation of adverse events. Secondly, overall and progression-free survival, as well as quality of life were evaluated for treated patients. According to the available data sources, there are no dose-escalation protocols available for the two studies (NCT02168270 and NCT02833701). Phase I study NCT02168270 investigating the synergetic temozolomide and ascorbate therapy procedure was terminated in 2018 due to lack of efficacy and owing to non-completion of study protocol for all four participants. Serious adverse events occurred in two individuals; however, it was not specified if the serious adverse events were ascorbate- or temozolomide-induced. For Phase I study NCT02833701, which assessed the effects and best dose of ascorbate when given together with bevacizumab, no results are published. Although both clinical trials are already terminated there are no results about detailed study outcomes publicly accessible (NCT02168270 in 2018 and NCT02833701 in 2019).

Notably, in the randomized Phase 2 clinical trial NCT03503864, the therapeutic efficacy and toxicity of arsenic trioxide in the treatment of patients with recurrent or refractory stage 4 neuroblastoma was evaluated. This study is actually under recruitment and is being conducted at Sun Yat-Sen University in China. Owing to the study protocol patients are due to receive chemotherapy combined with conventional induction therapy, additionally for intravenous injection, arsenic trioxide and simultaneously 0.5-1.0 g ascorbate in $5 \%$ glucose solution. Treatment is scheduled every 28 days for a maximum of nine cycles in the absence of disease progression or unacceptable toxicity. Therefore, the focus has been on the 3-year overall survival rate, progression-free survival, as well as incidence of adverse events. The study outcomes from the experimental group, treated with arsenic trioxide combined with induction chemotherapy, should be compared with the results from the control group which only received conventional induction chemotherapy without arsenic trioxide.

In addition, there is a number of studies focusing on oral ascorbate in high-grade re-occurrent glioma, glioblastoma, low- and high-risk neuroblastoma or brain tumors (NCT01891747, NCT04488783, NCT01811121, and NCT01502280). Admittedly, the ingestion of orally administered ascorbate is tightly controlled, and intravenous administration enables bypassing of the control mechanisms and yields up to 100-fold higher plasma levels than those possible with maximal oral dosing. With intravenous administration, ascorbate is turned from vitamin to drug, acting as a pro-drug for $\mathrm{H}_{2} \mathrm{O}_{2}$ in the extracellular fluid, thereby having potential in the treatment of cancer $(57,149)$. Therefore, the discussion of investigations with oral ascorbate supplementation is not in the scope of this review. The same applies for the two studies using palmitoyl ascorbate as excipient for rapamycin in the treatment of relapsed or refractory high-risk neuroblastoma and pineoblastoma in multimodal molecular-targeted therapy (NCT01467986 and NCT02596828). Overall, clinical trials employing intravenous vitamin $\mathrm{C}$ in critically ill patients (150-152) and patients with cancer $(40,50,96,97,140)$ have demonstrated a lack of toxicity, good safety, and tolerability (141). In the current study Phase I (NCT01752491) (146) and one case report (147) 
including glioblastoma patients, encouraging evidence was provided that receiving chemotherapy and radiotherapy together with high-dose ascorbate is beneficial.

\section{Future directions and amplification of therapy effects}

Modulation of microglia. Early studies on glioblastoma have been generally focused on the tumor-specific genetics and molecular profiles. However, tumor cells are not isolated and grow in a particular environment by communicating with other cell types, which influences progression, aggression, and survival of cancer. New investigations indicate that glioma cells interact in a complex way with their microenvironment promoting their proliferation, invasion, and treatment resistance (153).

Surrounding brain tumor-initiating cells are microglia, which are resident brain-specific immune cells of the CNS and distinct from peripheral circulating monocytes as well as other macrophages that have infiltrated from the circulation (154-158). These cells are believed to be initially recruited to eliminate the tumor by stimulating apoptosis of glioma cells (159) and by secreting inflammatory factors that prevent glioma growth and invasiveness (160). Under the influence of glioblastoma, microglia and macrophages are immunosuppressed and may contribute to glioblastoma invasion. Martins et al suggested that the local modulation of microglia within glioblastoma can control cancer cell progression by rendering microglial cell tumor-phagocytosis (161). Moreover, deficits of vitamin $\mathrm{C}$ in the brain have been observed in different neurological conditions and disorders, including Parkinson's and Alzheimer's disease, in which microglia pro-inflammatory activation influences their onset and/or progression (161).

Radiation and microglia homeostasis. Radiation therapy is one of the three standard of care components for glioblastoma. Radiation can kill proliferating tumor cells and severely impact the tumor microenvironment by altering the extracellular milieu at molecular and structural levels (162-164). Independent groups have documented enhanced human glioma cell migration and invasion in response to radiation (165-169). Gupta et al identified aggressive tumor behavior, microglial activation, and metabolic alterations with an increase of energy carriers (ATP and GTP) in the extracellular space as well as a decline in ascorbate in mice after radiation (170). Thus, microglia were observed to be amoeboid with higher phagocytic activity after radiation. In regard to the metabolic and morphologic changes in the radiated microenvironment, administration of ascorbate was suggested as an opportunity to decrease radiation-associated aggressiveness of recurrent glioblastoma and to enhance the long-term safety of brain radiation treatment for glioblastoma (170). SVCT2-deficient mice showed decreased ascorbate levels in the brain with a marked increase in cognitive deficits, amyloid $\beta$ accumulation, and oxidative stress (171). Portugal et al showed that reduced vitamin C uptake through SVCT2 triggers the activation of primary rodent and human microglia. Thus, modulation of SVCT2 or vitamin C supply may be an attractive strategy for restoring microglia homeostasis and promoting neuronal viability (172). Moreover, mitochondrial SVCT2 was previously described in U937 cells (173) and HEK293 cells (174) and it was also observed in various cancer-derived cell lines from different origin (175). This observation was also correlated with cancer pathology (175) and absent in normal cells, suggesting that mitochondrial vitamin $\mathrm{C}$ may be relevant for cancer cell development or survival (176).

Modulation of BBB tightness. The BBB is a specialized non-permeable barrier in cerebral microvessels. Tight junctions between endothelial cells in brain capillaries are the most prominent characteristic of the BBB and are responsible for its selectivity (177). Higher supplementation of vitamin $C$ in an in vivo mouse model revealed two times longer tight junctions than in low-dose supplemented animals (178). Behind the regeneration of DHA, derived from neuronal cells or delivered from blood, astrocytes also control BBB tightness. When these astrocytes become malignant as astrocytoma cells or are even turned into glioblastoma cells, the conditions within the brain become complex (179).

The impact of peroxiporins. Aquaporins (AQPs) have been described as crucial controllers of the BBB integrity and play an important role in cancer (180). Experimental evidence depicts that some AQPs also allow the transport of $\mathrm{H}_{2} \mathrm{O}_{2}$ through biological membranes. These AQPs are termed peroxiporins (181). Unlike normal cells, which are relatively unaffected by ascorbate, cancer cells exhibit a wide range of susceptibility depending on their catalase activity and plasma membrane permeability to $\mathrm{H}_{2} \mathrm{O}_{2}$. Erudaitius et al demonstrated that peroxiporin expression is an important factor for cancer cell susceptibility to therapeutic $\mathrm{H}_{2} \mathrm{O}_{2}$ (106). This suggests that cell susceptibility to ascorbate therapy is closely related to plasma membrane permeability to $\mathrm{H}_{2} \mathrm{O}_{2}$ in accordance with an elevated expression of peroxiporins. Therefore, modulation of plasma membrane is an option to increase the permeability of ascorbate. AQP1 and AQP4 upregulation which was observed in gliomas, glioblastomas, and also glioblastoma stem-like cells is believed to increase the perivascular space observed in gliomas (182-184). As $\mathrm{H}_{2} \mathrm{O}_{2}$ is known to be formed extracellularly as a byproduct of ascorbate oxidation and then permeating into the intracellular space through peroxiporin channeling $(27,103)$, the efficacy of pharmacological ascorbate therapy (185) in glioblastoma may depend on the presence of $\mathrm{H}_{2} \mathrm{O}_{2}$ and on peroxiporins to pass through the plasma membrane, respectively.

Modulation of ascorbate transporter expression. It is possible that ascorbate delivery or uptake into the cell is also altered due to vascular dysfunction and disorganization (186). GLUT1 and to a lesser extent GLUT3 may be promising targets for glioblastoma treatment. The Warburg Effect occurring in cancer cells, is characterized by an extreme increase of glycolysis thereby decreasing the dependence on oxidative phosphorylation. Expression of GLUT1 and GLUT3 in glioblastoma tissue is often markedly altered $(184,187,188)$. Co-culture experiments in the presence of ascorbate showed that tumor cells from CNS cells were able to acquire vitamin C via SVCT2; however, compared with normal cells, the capacity for ascorbate uptake was much lower in tumor cells (189). In this regard, it is important to emphasize 


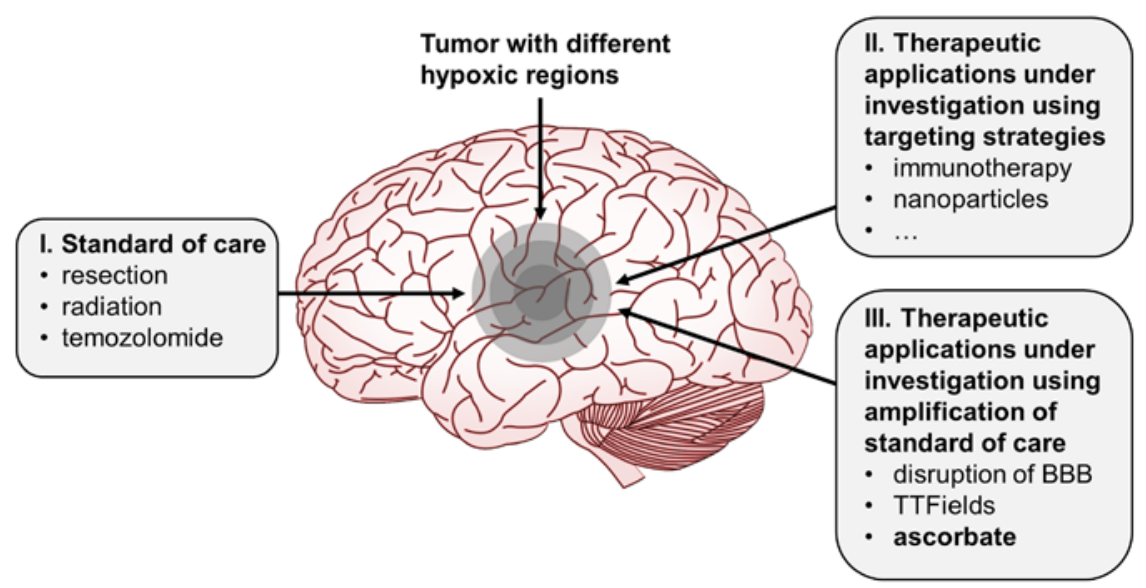

Figure 3. Overview of current therapeutic strategies and ongoing investigations in the glioblastoma treatment. There are three major parts in the treatment of glioblastoma: I. Standard of care (resection, radiation, and chemotherapy); II. Therapeutic applications under investigations using targeting strategies (immunotherapy, nanoparticles, and further therapeutic approaches); III. Therapeutic applications under investigation using amplification of standard of care [disruption of Blood Brain Barrier (BBB), TTFields, and ascorbate].

that the main form of vitamin $\mathrm{C}$ found after co-culture was ascorbate, meaning cancer cells are able to efficiently reduce DHA once inside the cell (175). Additionally, the competitive inhibition of GLUT transporters in glioblastoma cell lines did not suppress the ascorbate-induced toxicity suggesting that DHA is not the cancer cell-selective toxic species in this model $(26,28,102,190)$. Reactive astrocytes generated following brain injury, neuroinflammation, stroke, aging, or neurodegenerative diseases, were able to induce SVCT2 expression, probably as a neuroprotective strategy for oxidative defense (191). On the other hand, reactive astrocytes release cytokines, chemokines, interleukins, nitric oxide, and other molecules, thereby promoting neuroinflammation (192) and the development of tumor microenvironment $(155,189)$. Whether SVCT2 expression and function in reactive astrocytes may be considered a potential target for future clinical treatments remains to be further investigated.

The mechanism by which SVCT2 is upregulated in brain tissue is poorly understood. It has been observed that SVCT2 mRNA levels increase in neurons and astrocytes following oxidative damage due to ischemia and reperfusion (193). These findings underscore the importance of ascorbate as a neuroprotective agent and may have implications for therapeutic strategies. Induction of CNS inflammation resulted in the internalization and degradation of SVCT2 in microglia followed by the activation of $\mathrm{NF \kappa B}$ (172). In $\mathrm{C} 2 \mathrm{C} 12$ cells, it has been determined that the activation of NFKB and AP-1 would increase SVCT2 expression under conditions of oxidative stress generated by $\mathrm{H}_{2} \mathrm{O}_{2}$ (194). However, the whole picture of the interactions between microglia, astrocytes from tumor-unaffected regions, activated astrocytes, brain tumor-initiating cells, neurons, and tumor cells requires further exploration in glioblastoma patients and after treatment with high-dose ascorbate.

\section{Conclusion}

Despite advances in surgical techniques, radiation therapy, and chemotherapy, effective treatment of glioblastoma remains an unresolved challenge (8) (Fig. 3). In general, oncologic patients have decreased vitamin $\mathrm{C}$ levels, which are likely due to enhanced metabolic turnover as a result of oxidative and inflammatory aspects of the disease process (195). Nevertheless, the role of vitamin $C$ in cancer patients is not fully clarified $(73,196,197)$. Enhanced oxidative stress and pro-inflammatory biomarkers can also result from chemotherapy $(198,199)$ or radiation $(170)$. At present, only a small number of studies including glioblastoma patients and testing ascorbate as a potential therapeutic agent are available. The combination of pharmacological ascorbate with radiation and temozolomide provides hope to improve the patient's treatment performance as well as to ameliorate their life quality $(47,146)$.

Although the data from in vitro and rodent models demonstrate effectiveness of ascorbate in the glioblastoma $(146,147,200)$, its function mechanistically in healthy and glioblastoma subjects remains to be elucidated. Future investigations therefore have to clarify whether high-dose ascorbate is able to pass through the BBB in cancer patients, to reach all tumor cells at a sufficient concentration, to penetrate the hypoxic, inhomogeneous, and highly disorganized tissue, and to produce radicals as well as $\mathrm{H}_{2} \mathrm{O}_{2}$ to be pro-oxidative. Delivery of antioxidants such as vitamin $\mathrm{C}$ (or the more stable palmitoyl ascorbate) or $\alpha$ lipoic acid by liposomes seems to be a suitable approach to overcome limitations, including low bioavailability and instability, and can result in cancer tissue accumulation (201). These approaches to increase CNS drug levels are also promising strategies to apply high-dose ascorbate in glioma patients. Otherwise, the prolongation of supra-physiological ascorbate plasma levels over $2 \mathrm{~h}$ may act longer synergistically with drugs and positively increase the efficacy of therapy outcomes in general. On the other hand, making life more commodious for patients is imperative. Therefore, the reduction of ascorbate infusion's application frequency may contribute to a more satisfactory quality of life. Further development of nanomaterials-based strategies or other methods may contribute to improve ascorbate delivery to the tumor and to act on targeted transporters for inducing tumor-toxicities and cell protection, respectively. Sufficient 
brain substance/drug delivery remains a major challenge for a wide range of neurological disorders and especially for glioblastoma. Nanomaterials can make use of mechanisms such as BBB-crossing mediated by cell-penetrating peptides (202), receptors (203), shuttle peptides (204), or even certain types of cells including macrophages, neutrophils, and monocytes (205). The combination of therapy regimes by integrating synergistic effects could overcome the limitations of a respective monotherapy and reinforce antitumor immunity or decrease tumor growth $(206,207)$.

There is strong evidence that the effects of high-dose ascorbate treatment in glioma are not only restricted to general anti-oxidative effects that protect non-malignant and non-brain cells from the cytotoxic effects of chemotherapy and radiation $(26,28,29,32)$. Additional investigations are required to explore whether adjuvant ascorbate therapy is also beneficial or even conflicting in combination with immunotherapy or oncolytic virotherapy treatment approaches.

Nevertheless, adjuvant high-dose ascorbate treatment in glioblastoma patients seems to be a promising therapeutic option that is able to improve the survival and quality of life of glioblastoma patients according to the available data from in vitro and in vivo studies. As the application of intravenous infusion is a routine standard procedure in the hospitalized patient's treatment, administration of pharmacological ascorbate requires no additional expertise for the staff, even more because the intravenous solutions are notably stable at ambient temperature (208).

\section{Acknowledgements}

We thank Christian Leischner and Andreas Burkard for their excellent technical support. We further acknowledge support by the Open Access Publishing Fund of University of Tuebingen.

\section{Funding}

SV and MB were supported by the Else-Uebelmesser-Stiftung (grant no. D.30.21947) and the Ministry for Rural Affairs and Consumer Protection Baden-Wuerttemberg (grant no. 14-(34)-0802/0402 E). SV and TS were supported by a grant from Pascoe pharmazeutische Praeparate $\mathrm{GmbH}$ (grant no. D.24.01029). CV and HM are employed at Pascoe Pharmazeutische Praeparate GmbH (Giessen, Germany).

\section{Availability and of data and materials}

Not applicable.

\section{Authors' contributions}

OR, MB, TS, and SV wrote and conceived the manuscript. $\mathrm{OR}$ and MB carried out the literature and study research and generated the figures. HM and CV revised the manuscript. All authors read and approved the final manuscript. OR and MB confirm the authenticity of the data.

\section{Ethics approval and consent to participate}

Not applicable.

\section{Patient consent for publication}

Not applicable.

\section{Competing interests}

OR, MB, TS, and SV declare that they have no competing interests. CV and HM, as employees of Pascoe Pharmazeutische Praeparate $\mathrm{GmbH}$ (Giessen, Germany), received the ready designed/written manuscript for their review and were not involved in the content-related structuring. Furthermore, CV and HM had no influence on the content and interpretation of the literature used.

\section{References}

1. Louis DN, Perry A, Reifenberger G, von Deimling A, Figarella-Branger D, Cavenee WK, Ohgaki H, Wiestler OD, Kleihues P and Ellison DW: The 2016 world health organization classification of tumors of the central nervous system: A summary. Acta Neuropathol 131: 803-820, 2016.

2. Silantyev AS, Falzone L, Libra M, Gurina OI, Kardashova KS, Nikolouzakis TK, Nosyrev AE, Sutton CW, Mitsias PD and Tsatsakis A: Current and future trends on diagnosis and prognosis of glioblastoma: From molecular biology to proteomics. Cells 8: 863, 2019.

3. Candido S, Lupo G, Pennisi M, Basile MS, Anfuso CD, Petralia MC, Gattuso G, Vivarelli S, Spandidos DA, Libra M and Falzone L: The analysis of miRNA expression profiling datasets reveals inverse microRNA patterns in glioblastoma and Alzheimer's disease. Oncol Rep 42: 911-922, 2019.

4. Armento A, Ehlers J, Schötterl S and Naumann U: Molecular mechanisms of glioma cell motility. In: Glioblastoma. De Vleeschouwer S (ed). Codon Publications, Brisbane, 2017.

5. Tabatabai $\mathrm{G}$ and Wakimoto H: Glioblastoma: State of the Art and future perspectives. Cancers (Basel) 11: 1091, 2019.

6. Ohgaki $\mathrm{H}$ and Kleihues P: Epidemiology and etiology of gliomas. Acta Neuropathol 109: 93-108, 2005.

7. Ostrom QT, Gittleman H, Stetson L, Virk S and BarnholtzSloan JS: Epidemiology of intracranial gliomas. Prog Neurol Surg 30: 1-11, 2018.

8. Stupp R, Mason WP, van den Bent MJ, Weller M, Fisher B, Taphoorn MJ, Belanger K, Brandes AA, Marosi C, Bogdahn U, et al: Radiotherapy plus concomitant and adjuvant temozolomide for glioblastoma. N Engl J Med 352: 987-996, 2005.

9. Weller M, Butowski N, Tran DD, Recht LD, Lim M, Hirte H, Ashby L, Mechtler L, Goldlust SA, Iwamoto F, et al: Rindopepimut with temozolomide for patients with newly diagnosed, EGFRvIII-expressing glioblastoma (ACT IV): A randomised, double-blind, international phase 3 trial. Lancet Oncol 18: 1373-1385, 2017.

10. Tian M, Ma W, Chen Y, Yu Y, Zhu D, Shi J and Zhang Y: Impact of gender on the survival of patients with glioblastoma. Biosci Rep: Nov 7, 2018 (Epub ahead of print). doi: 10.1042/BSR20180752.

11. Brat DJ, Aldape K, Colman H,Holland EC, Louis DN, Jenkins RB, Kleinschmidt-DeMasters BK, Perry A, Reifenberger G, Stupp R, et al: cIMPACT-NOW update 3: Recommended diagnostic criteria for 'Diffuse astrocytic glioma, IDH-wildtype, with molecular features of glioblastoma, WHO grade IV'. Acta Neuropathol 136: 805-810, 2018.

12. Zhao H, Zhu H, Huang J, Zhu Y, Hong M, Zhu H, Zhang J, Li S, Yang L, Lian Y, et al: The synergy of vitamin C with decitabine activates TET2 in leukemic cells and significantly improves overall survival in elderly patients with acute myeloid leukemia. Leuk Res 66: 1-7, 2018.

13. García MG, Carella A, Urdinguio RG, Bayón GF, Lopez V, Tejedor JR, Sierra MI, García-Toraño E, Santamarina P, Perez RF, et al: Epigenetic dysregulation of TET2 in human glioblastoma. Oncotarget 9: 25922-25934, 2018.

14. Mansouri A, Hachem LD, Mansouri S, Nassiri F, Laperriere NJ, Xia D, Lindeman NI, Wen PY, Chakravarti A, Mehta MP, et al: MGMT promoter methylation status testing to guide therapy for glioblastoma: Refining the approach based on emerging evidence and current challenges. Neuro Oncol 21: 167-178, 2019. 
15. Stummer W, Pichlmeier U, Meinel T, Wiestler OD, Zanella F and Reulen HJ; ALA-Glioma Study Group: Fluorescence-guided surgery with 5-aminolevulinic acid for resection of malignant glioma: A randomised controlled multicentre phase III trial. Lancet Oncol 7: 392-401, 2006.

16. Pichlmeier U, Bink A, Schackert G and Stummer W; ALA Glioma Study Group: Resection and survival in glioblastoma multiforme: An RTOG recursive partitioning analysis of ALA study patients. Neuro Oncol 10: 1025-1034, 2008.

17. Abd-El-Barr MM and Chiocca EA: How much is enough? The question of extent of resection in glioblastoma multiforme. World Neurosurg 82: e109-e110, 2014.

18. Ryken TC, Parney I, Buatti J, Kalkanis SN and Olson JJ: The role of radiotherapy in the management of patients with diffuse low grade glioma: A systematic review and evidence-based clinical practice guideline. J Neurooncol 125: 551-583, 2015.

19. Niyazi M, Brada M, Chalmers AJ, Combs SE, Erridge SC, Fiorentino A, Grosu AL, Lagerwaard FJ, Minniti G, Mirimanoff RO, et al: ESTRO-ACROP guideline 'target delineation of glioblastomas'. Radiother Oncol 118: 35-42, 2016.

20. Wick W, Platten M, Meisner C, Felsberg J, Tabatabai G, Simon M, Nikkhah G, Papsdorf K, Steinbach JP, Sabel M, et al: Temozolomide chemotherapy alone versus radiotherapy alone for malignant astrocytoma in the elderly: The NOA-08 randomised, phase 3 trial. Lancet Oncol 13: 707-715, 2012.

21. Rusthoven CG, Koshy M and Sher DJ: Radiation plus temozolomide in patients with glioblastoma. N Engl J Med 376: 2195-2197, 2017.

22. Perry JR, Laperriere N, O'Callaghan CJ, Brandes AA, Menten J, Phillips C, Fay M, Nishikawa R, Cairncross JG, Roa W, et al Short-course radiation plus temozolomide in elderly patients with glioblastoma. N Engl J Med 376: 1027-1037, 2017.

23. McGranahan T, Therkelsen KE, Ahmad S and Nagpal S: Current state of immunotherapy for treatment of glioblastoma. Curr Treat Options Oncol 20: 24, 2019.

24. Rominiyi O, Vanderlinden A, Clenton SJ, Bridgewater C, Al-Tamimi $\mathrm{Y}$ and Collis SJ: Tumour treating fields therapy for glioblastoma: Current advances and future directions. Br J Cancer 124: 697-709, 2021.

25. Geletneky K, Hajda J, Angelova AL, Leuchs B, Capper D, Bartsch AJ, Neumann JO, Schöning T, Hüsing J, Beelte B, et al: Oncolytic H-1 parvovirus shows safety and signs of immunogenic activity in a first phase I/IIa glioblastoma trial. Mol Ther 25: 2620-2634, 2017.

26. Chen Q, Espey MG, Krishna MC, Mitchell JB, Corpe CP Buettner GR, Shacter E and Levine M: Pharmacologic ascorbic acid concentrations selectively kill cancer cells: Action as a pro-drug to deliver hydrogen peroxide to tissues. Proc Natl Acad Sci USA 102: 13604-13609, 2005.

27. Chen Q, Espey MG, Sun AY, Lee JH, Krishna MC, Shacter E, Choyke PL, Pooput C, Kirk KL, Buettner GR and Levine M: Ascorbate in pharmacologic concentrations selectively generates ascorbate radical and hydrogen peroxide in extracellular fluid in vivo. Proc Natl Acad Sci USA 104: 8749-8754, 2007.

28. Schoenfeld JD, Sibenaller ZA, Mapuskar KA, Wagner BA, Cramer-Morales KL, Furqan $M$, Sandhu S, Carlisle TL, Smith MC, Abu Hejleh T, et al: $\mathrm{O}_{2}{ }^{-}$and $\mathrm{H}_{2} \mathrm{O}_{2}$-mediated disruption of fe metabolism causes the differential susceptibility of NSCLC and GBM cancer cells to pharmacological ascorbate. Cancer Cell 32: 268, 2017.

29. Klingelhoeffer C, Kämmerer U, Koospal M, Mühling B Schneider M, Kapp M, Kübler A, Germer CT and Otto C: Natural resistance to ascorbic acid induced oxidative stress is mainly mediated by catalase activity in human cancer cells and catalase-silencing sensitizes to oxidative stress. BMC Complement Altern Med 12: 61, 2012.

30. Sauberlich HE: Pharmacology of vitamin C. Annu Rev Nutr 14 371-391, 1994

31. Nishikimi M and Yagi K: Molecular basis for the deficiency in humans of gulonolactone oxidase, a key enzyme for ascorbic acid biosynthesis. Am J Clin Nutr 54 (Suppl 6): 1203S-1208S, 1991.

32. Padayatty SJ and Levine M: Vitamin C: The known and the unknown and goldilocks. Oral Dis 22: 463-493, 2016.

33. Carr A and Frei B: Does vitamin C act as a pro-oxidant under physiological conditions? FASEB J 13: 1007-1024, 1999.

34. Levine M, Wang Y, Katz A, Eck P, Kwon O, Chen S, Lee JH and Padayatty SJ: Ideal vitamin C intake. Biofactors 15: 71-74, 2001.

35. Carr AC and Lykkesfeldt J: Discrepancies in global vitamin C recommendations: A review of RDA criteria and underlying health perspectives. Crit Rev Food Sci Nutr 61: 742-755, 2021.
36. Levine M, Conry-Cantilena C, Wang Y, Welch RW, Washko PW, Dhariwal KR, Park JB, Lazarev A, Graumlich JF, King J and Cantilena LR: Vitamin C pharmacokinetics in healthy volunteers: Evidence for a recommended dietary allowance. Proc Natl Acad Sci USA 93: 3704-3709, 1996.

37. Hoffer LJ, Levine M, Assouline S, Melnychuk D, Padayatty SJ, Rosadiuk K, Rousseau C, Robitaille L and Miller WH Jr: Phase I clinical trial of i.v. ascorbic acid in advanced malignancy. Ann Oncol 19: 1969-1974, 2008

38. Padayatty SJ, Sun AY, Chen Q, Espey MG, Drisko J and Levine M: Vitamin C: Intravenous use by complementary and alternative medicine practitioners and adverse effects. PLoS One 5: e11414, 2010.

39. Nielsen TK, Højgaard M, Andersen JT, Poulsen HE, Lykkesfeldt J and Mikines KJ: Elimination of ascorbic acid after high-dose infusion in prostate cancer patients: A pharmacokinetic evaluation. Basic Clin Pharmacol Toxicol 116: 343-348, 2015.

40. Stephenson CM, Levin RD, Spector T and Lis CG: Phase I clinical trial to evaluate the safety, tolerability, and pharmacokinetics of high-dose intravenous ascorbic acid in patients with advanced cancer. Cancer Chemother Pharmacol 72: 139-146, 2013.

41. Torun M, Yardim S, Gönenç A, Sargin H, Menevşe A and Símsek B: Serum beta-carotene, vitamin E, vitamin C and malondialdehyde levels in several types of cancer. J Clin Pharm Ther 20: 259-263, 1995.

42. Mahdavi R, Faramarzi E, Seyedrezazadeh E, MohammadZadeh $\mathrm{M}$ and Pourmoghaddam M: Evaluation of oxidative stress, antioxidant status and serum vitamin $\mathrm{C}$ levels in cancer patients. Biol Trace Elem Res 130: 1-6, 2009.

43. Sharma A, Tripathi M, Satyam A and Kumar L: Study of antioxidant levels in patients with multiple myeloma. Leuk Lymphoma 50: 809-815, 2009.

44. Emri S, Kilickap S, Kadilar C, Halil MG, Akay H and Besler T: Serum levels of alpha-tocopherol, vitamin C, beta-carotene, and retinol in malignant pleural mesothelioma. Asian Pac J Cancer Prev 13: 3025-3029, 2012.

45. Mehdi WA, Zainulabdeen JA and Mehde AA: Investigation of the antioxidant status in multiple myeloma patients: Effects of therapy. Asian Pac J Cancer Prev 14: 3663-3667, 2013.

46. Huijskens MJ, Wodzig WK, Walczak M, Germeraad WT and Bos GM: Ascorbic acid serum levels are reduced in patients with hematological malignancies. Results Immunol 6: 8-10, 2016.

47. Fain O, Mathieu E and Thomas M: Scurvy in patients with cancer. BMJ 316: 1661-1662, 1998.

48. Mayland CR, Bennett MI and Allan K: Vitamin C deficiency in cancer patients. Palliat Med 19: 17-20, 2005.

49. Riordan HD, Riordan NH, Jackson JA, Casciari JJ, Hunninghake R, González MJ, Mora EM, Miranda-Massari JR, Rosario $\mathrm{N}$ and Rivera $\mathrm{A}$ : Intravenous vitamin $\mathrm{C}$ as a chemotherapy agent: A report on clinical cases. P R Health Sci J 23: $115-118,2004$

50. Hoffer LJ, Robitaille L, Zakarian R, Melnychuk D, Kavan P, Agulnik J, Cohen V, Small D and Miller WH Jr: High-dose intravenous vitamin $C$ combined with cytotoxic chemotherapy in patients with advanced cancer: A phase I-II clinical trial. PLoS One 10: $0120228,2015$.

51. Liu M, Ohtani H, Zhou W, Ørskov AD, Charlet J, Zhang YW, Shen H, Baylin SB, Liang G, Grønbæk K and Jones PA: Vitamin $\mathrm{C}$ increases viral mimicry induced by 5 -aza-2'-deoxycytidine. Proc Natl Acad Sci USA 113: 10238-10244, 2016.

52. Shenoy N,Bhagat T, Nieves E, Stenson M,Lawson J, Choudhary GS, Habermann T, Nowakowski G, Singh R, Wu X, et al: Upregulation of TET activity with ascorbic acid induces epigenetic modulation of lymphoma cells. Blood Cancer J 7: e587, 2017.

53. Anthony HM and Schorah CJ: Severe hypovitaminosis C in lung-cancer patients: The utilization of vitamin $\mathrm{C}$ in surgical repair and lymphocyte-related host resistance. Br J Cancer 46: 354-367, 1982.

54. Ramaswamy $\mathrm{G}$ and Krishnamoorthy L: Serum carotene, vitamin $\mathrm{A}$, and vitamin $\mathrm{C}$ levels in breast cancer and cancer of the uterine cervix. Nutr Cancer 25: 173-177, 1996.

55. Khanzode SS, Muddeshwar MG, Khanzode SD and Dakhale GN: Antioxidant enzymes and lipid peroxidation in different stages of breast cancer. Free Radic Res 38: 81-85, 2004.

56. Popa-Wagner A, Mitran S, Sivanesan S, Chang E and Buga AM ROS and brain diseases: The good, the bad, and the ugly. Oxid Med Cell Longev 2013: 963520, 2013.

57. Levine M, Padayatty SJ and Espey MG: Vitamin C: A concentration-function approach yields pharmacology and therapeutic discoveries. Adv Nutr 2: 78-88, 2011. 
58. Du J, Cullen JJ and Buettner GR: Ascorbic acid: Chemistry, biology and the treatment of cancer. Biochim Biophys Acta 1826: 443-457, 2012

59. Harrison FE and May JM: Vitamin C function in the brain Vital role of the ascorbate transporter SVCT2. Free Radic Biol Med 46: 719-730, 2009

60. Kaźmierczak-Barańska J, Boguszewska K, Adamus-Grabicka A and Karwowski BT: Two faces of vitamin C-antioxidative and pro-oxidative agent. Nutrients 12: 1501, 2020.

61. Lykkesfeldt $\mathbf{J}$ and Tveden-Nyborg P: The pharmacokinetics of vitamin C. Nutrients 11: 2412, 2019.

62. Abbott NJ: Dynamics of CNS barriers: Evolution, differentiation, and modulation. Cell Mol Neurobiol 25: 5-23, 2005.

63. Nualart F, Mack L, García A, Cisternas P, Bongarzone ER, Heitzer M, Jara N, Martínez F, Ferrada L, Espinoza F, et al: Vitamin $\mathrm{C}$ transporters, recycling and the bystander effect in the nervous system: SVCT2 versus gluts. J Stem Cell Res Ther 4 209, 2014.

64. Angelow S, Haselbach M and Galla HJ: Functional characterisation of the active ascorbic acid transport into cerebrospinal fluid using primary cultured choroid plexus cells. Brain Res 988 : 105-113, 2003.

65. Haselbach M, Wegener J, Decker S, Engelbertz C and Galla HJ: Porcine choroid plexus epithelial cells in culture: Regulation of barrier properties and transport processes. Microsc Res Tech 52 137-152, 2001

66. Shi LZ, Li GJ, Wang S and Zheng W: Use of Z310 cells as an in vitro blood-cerebrospinal fluid barrier model: Tight junction proteins and transport properties. Toxicol In Vitro 22: 190-199, 2008.

67. Strazielle N and Ghersi-Egea JF: Demonstration of a coupled metabolism-efflux process at the choroid plexus as a mechanism of brain protection toward xenobiotics. J Neurosci 19: 6275-6289, 1999.

68. Sotiriou S, Gispert S, Cheng J, Wang Y, Chen A, HoogstratenMiller S, Miller GF, Kwon O, Levine M, Guttentag SH and Nussbaum RL: Ascorbic-acid transporter Slc23a1 is essential for vitamin $\mathrm{C}$ transport into the brain and for perinatal survival. Nat Med 8: 514-517, 2002.

69. Tsukaguchi H, Tokui T, Mackenzie B, Berger UV, Chen XZ, Wang Y, Brubaker RF and Hediger MA: A family of mammalian $\mathrm{Na}$-dependent L-ascorbic acid transporters. Nature 399: 70-75, 1999.

70. Daruwala R, Song J, Koh WS, Rumsey SC and Levine M: Cloning and functional characterization of the human sodium-dependent vitamin C transporters hSVCT1 and hSVCT2. FEBS Lett 460 : 480-484, 1999

71. Wang D, Christensen K, Chawla K, Xiao G, Krebsbach PH and Franceschi RT: Isolation and characterization of MC3T3-E1 preosteoblast subclones with distinct in vitro and in vivo differentiation/mineralization potential. J Bone Miner Res 14 893-903, 1999

72. Wang Y, Mackenzie B, Tsukaguchi H, Weremowicz S, Morton CC and Hediger MA: Human vitamin C (L-ascorbic acid) transporter SVCT1. Biochem Biophys Res Commun 267: 488-494, 2000

73. Wohlrab C, Phillips E and Dachs GU: Vitamin C transporters in cancer: Current understanding and gaps in knowledge. Front Oncol 7: 74, 2017

74. Agus DB, Gambhir SS, Pardridge WM, Spielholz C, Baselga J, Vera JC and Golde DW: Vitamin C crosses the blood-brain barrier in the oxidized form through the glucose transporters. J Clin Invest 100: 2842-2848, 1997.

75. Ho HTB, Dahlin A and Wang J: Expression profiling of solute carrier gene families at the blood-CSF barrier. Front Pharmacol 3 : $154,2012$.

76. Bürzle M, Suzuki Y, Ackermann D, Miyazaki H, Maeda N, Clémençon B, Burrier R and Hediger MA: The sodium-dependent ascorbic acid transporter family SLC23. Mol Aspects Med 34: 436-454, 2013

77. Rice ME: Ascorbate regulation and its neuroprotective role in the brain. Trends Neurosci 23: 209-216, 2000.

78. Spector R, Keep RF, Robert Snodgrass S, Smith QR and Johanson CE: A balanced view of choroid plexus structure and function: Focus on adult humans. Exp Neurol 267: 78-86, 2015.

79. Mun GH, Kim MJ, Lee JH, Kim HJ, Chung YH, Chung YB, Kang JS, Hwang YI, Oh SH, Kim JG, et al: Immunohistochemical study of the distribution of sodium-dependent vitamin C transporters in adult rat brain. J Neurosci Res 83: 919-928, 2006.
80. Ulloa V, García-Robles M, Martínez F, Salazar K, Reinicke K, Pérez F, Godoy DF, Godoy AS and Nualart F: Human choroid plexus papilloma cells efficiently transport glucose and vitamin C. J Neurochem 127: 403-414, 2013.

81. Rice M and Russo-Menna I: Differential compartmentalization of brain ascorbate and glutathione between neurons and glia. Neuroscience 82: 1213-1223, 1998.

82. Castro M, Caprile T, Astuya A, Millán C, Reinicke K, Vera JC, Vásquez O, Aguayo LG and Nualart F: High-affinity sodium-vitamin C co-transporters (SVCT) expression in embryonic mouse neurons. J Neurochem 78: 815-823, 2001.

83. Nualart FJ, Rivas CI, Montecinos VP, Godoy AS, Guaiquil VH, Golde DW and Vera JC: Recycling of vitamin C by a bystander effect. J Biol Chem 278: 10128-10133, 2003.

84. Kaufman S: Coenzymes and hydroxylases: Ascorbate and dopamine-beta-hydroxylase; tetrahydropteridines and phenylalanine and tyrosine hydroxylases. Pharmacol Rev 18: 61-69, 1966.

85. Eipper BA, Milgram SL, Husten EJ, Yun HY and Mains RE: Peptidylglycine alpha-amidating monooxygenase: A multifunctional protein with catalytic, processing, and routing domains. Protein Sci 2: 489-497, 1993.

86. Eldridge CF, Bunge MB, Bunge RP and Wood PM: Differentiation of axon-related Schwann cells in vitro. I. Ascorbic acid regulates basal lamina assembly and myelin formation. J Cell Biol 105: 1023-1034, 1987.

87. Qiu S, Li L, Weeber EJ and May JM: Ascorbate transport by primary cultured neurons and its role in neuronal function and protection against excitotoxicity. J Neurosci Res 85: 1046-1056, 2007.

88. Rebec GV and Pierce RC: A vitamin as neuromodulator: Ascorbate release into the extracellular fluid of the brain regulates dopaminergic and glutamatergic transmission. Prog Neurobiol 43: 537-565, 1994

89. Pastor P, Cisternas P, Salazar K, Silva-Alvarez C, Oyarce K, Jara N, Espinoza F, Martínez AD and Nualart F: SVCT2 vitamin $\mathrm{C}$ transporter expression in progenitor cells of the postnatal neurogenic niche. Front Cell Neurosci 7: 119, 2013.

90. Oyarce K, Bongarzone ER and Nualart F: Unconventional neurogenic niches and neurogenesis modulation by vitamins. J Stem Cell Res Ther 4: 184, 2014.

91. Davson H and Oldendorf WH: Symposium on membrane transport. Transport in the central nervous system. Proc R Soc Med 60: 326-329, 1967.

92. Reiber H, Ruff M and Uhr M: Ascorbate concentration in human cerebrospinal fluid (CSF) and serum. Intrathecal accumulation and CSF flow rate. Clinica Chimica Acta 217: 163-173, 1993.

93. Cameron E and Pauling L: Supplemental ascorbate in the supportive treatment of cancer: Prolongation of survival times in terminal human cancer. Proc Natl Acad Sci USA 73: 3685-3689, 1976.

94. Creagan ET, Moertel CG, O'Fallon JR, Schutt AJ, O'Connell MJ, Rubin $J$ and Frytak S: Failure of high-dose vitamin $C$ (ascorbic acid) therapy to benefit patients with advanced cancer. A controlled trial. N Engl J Med 301: 687-690, 1979.

95. Moertel CG, Fleming TR, Creagan ET, Rubin J, O'Connell MJ and Ames MM: High-dose vitamin $C$ versus placebo in the treatment of patients with advanced cancer who have had no prior chemotherapy. A randomized double-blind comparison. N Engl J Med 312: 137-141, 1985

96. Monti DA, Mitchell E, Bazzan AJ, Littman S, Zabrecky G, Yeo CJ, Pillai MV, Newberg AB, Deshmukh S and Levine M: Phase I evaluation of intravenous ascorbic acid in combination with gemcitabine and erlotinib in patients with metastatic pancreatic cancer. PLoS One 7: e29794, 2012.

97. Welsh JL, Wagner BA, van't Erve TJ, Zehr PS, Berg DJ, Halfdanarson TR, Yee NS, Bodeker KL, Du J, Roberts LJ II, et al: Pharmacological ascorbate with gemcitabine for the control of metastatic and node-positive pancreatic cancer (PACMAN): Results from a phase I clinical trial. Cancer Chemother Pharmacol 71: 765-775, 2013.

98. Herst PM, Broadley KWR, Harper JL and McConnell MJ: Pharmacological concentrations of ascorbate radiosensitize glioblastoma multiforme primary cells by increasing oxidative DNA damage and inhibiting G2/M arrest. Free Radic Biol Med 52: 1486-1493, 2012

99. Ma Y, Chapman J, Levine M, Polireddy K, Drisko J and Chen Q: High-dose parenteral ascorbate enhanced chemosensitivity of ovarian cancer and reduced toxicity of chemotherapy. Sci Transl Med 6: 222ra18, 2014 
100. Fritz H, Flower G, Weeks L, Cooley K, Callachan M, McGowan J, Skidmore B, Kirchner L and Seely D: Intravenous vitamin $\mathrm{C}$ and cancer: $\mathrm{A}$ systematic review. Integr Cancer Ther 13: 280-300, 2014.

101. Carr AC and Cook J: Intravenous vitamin C for cancer therapy-identifying the current gaps in our knowledge. Front Physiol 9: 1182, 2018.

102. Violet PC and Levine M: Pharmacologic ascorbate in myeloma treatment: Doses matter. EBioMedicine 18: 9-10, 2017.

103. Schoenfeld JD, Alexander MS, Waldron TJ, Sibenaller ZA Spitz DR, Buettner GR, Allen BG and Cullen JJ: Pharmacological ascorbate as a means of sensitizing cancer cells to radio-chemotherapy while protecting normal tissue. Semin Radiat Oncol 29 25-32, 2019

104. Bienert GP, Schjoerring JK and Jahn TP: Membrane transport of hydrogen peroxide. Biochim Biophys Acta 1758: 994-1003, 2006.

105. Bienert GP, Møller AL, Kristiansen KA, Schulz A, Møller IM, Schjoerring JK and Jahn TP: Specific aquaporins facilitate the diffusion of hydrogen peroxide across membranes. J Biol Chem 282: 1183-1192, 2007.

106. Erudaitius D, Huang A, Kazmi S, Buettner GR and Rodgers VG: Peroxiporin expression is an important factor for cancer cell susceptibility to therapeutic $\mathrm{H}_{2} \mathrm{O}_{2}$ : Implications for pharmacological ascorbate therapy. PLoS One 12: e0170442, 2017.

107. Deubzer B, Mayer F, Kuçi Z, Niewisch M, Merkel G, Handgretinger $\mathrm{R}$ and Bruchelt $\mathrm{G}: \mathrm{H}(2) \mathrm{O}(2)$-mediated cytotoxicity of pharmacologic ascorbate concentrations to neuroblastoma cells: Potential role of lactate and ferritin. Cell Physiol Biochem 25: 767-774, 2010

108. Olney KE, Du J, van 't Erve TJ, Witmer JR, Sibenaller ZA, Wagner BA, Buettner GR and Cullen JJ: Inhibitors of hydroperoxide metabolism enhance ascorbate-induced cytotoxicity. Free Radic Res 47: 154-163, 2013.

109. Du J, Martin SM, Levine M, Wagner BA, Buettner GR, Wang S, Taghiyev AF, Du C, Knudson CM and Cullen JJ: Mechanisms of ascorbate-induced cytotoxicity in pancreatic cancer. Clin Cancer Res 16: 509-520, 2010.

110. Ibrahim WH, Habib HM, Kamal H, St Clair DK and Chow CK Mitochondrial superoxide mediates labile iron level: Evidence from Mn-SOD-transgenic mice and heterozygous knockout mice and isolated rat liver mitochondria. Free Radic Biol Med 65: 143-149, 2013.

111. Doskey CM, Buranasudja V, Wagner BA, Wilkes JG, Du J, Cullen JJ and Buettner GR: Tumor cells have decreased ability to metabolize $\mathrm{H}_{2} \mathrm{O}_{2}$ : Implications for pharmacological ascorbate in cancer therapy. Redox Biol 10: 274-284, 2016.

112. Sinnberg T, Noor S, Venturelli S, Berger A, Schuler P, Garbe C and Busch C: The ROS-induced cytotoxicity of ascorbate is attenuated by hypoxia and HIF-1alpha in the NCI60 cancer cell lines. J Cell Mol Med 18: 530-541, 2014

113. Du J, Cieslak JA III, Welsh JL, Sibenaller ZA, Allen BG, Wagner BA, Kalen AL, Doskey CM, Strother RK, Button AM, et al Pharmacological ascorbate radiosensitizes pancreatic cancer. Cancer Res 75: 3314-3326, 2015.

114. Torti SV and Torti FM: Iron and cancer: More ore to be mined. Nat Rev Cancer 13: 342-355, 2013.

115. Uetaki M,TabataS,NakasukaF,SogaT andTomita M:Metabolomic alterations in human cancer cells by vitamin $\mathrm{C}$-induced oxidative stress. Sci Rep 5: 13896, 2015.

116. El Banna N, Hatem E, Heneman-Masurel A, Léger T, Baïlle D, Vernis L, Garcia C, Martineau S, Dupuy C, Vagner S, et al: Redox modifications of cysteine-containing proteins, cell cycle arrest and translation inhibition: Involvement in vitamin C-induced breast cancer cell death. Redox Biol 26: 101290, 2019.

117. Frömberg A, Gutsch D, Schulze D, Vollbracht C, Weiss G, Czubayko $\mathrm{F}$ and Aigner A: Ascorbate exerts anti-proliferative effects through cell cycle inhibition and sensitizes tumor cells towards cytostatic drugs. Cancer Chemother Pharmacol 67: 1157-1166, 2011.

118. Marklund SL, Westman NG, Lundgren E and Roos G: Copper- and zinc-containing superoxide dismutase, manganese-containing superoxide dismutase, catalase, and glutathione peroxidase in normal and neoplastic human cell lines and normal human tissues. Cancer Res 42: 1955-1961, 1982.

119. Johnson RM, Ho YS, Yu DY, Kuypers FA, Ravindranath Y and Goyette GW: The effects of disruption of genes for peroxiredoxin-2, glutathione peroxidase-1, and catalase on erythrocyte oxidative metabolism. Free Radic Biol Med 48: 519-525, 2010.

120. Vaupel P, Höckel M and Mayer A: Detection and characterization of tumor hypoxia using pO2 histography. Antioxid Redox Signal 9: 1221-1235, 2007.
121. Moulder JE and Rockwell S: Hypoxic fractions of solid tumors: Experimental techniques, methods of analysis, and a survey of existing data. Int J Radiat Oncol Biol Phys 10: 695-712, 1984.

122. Vaupel P, Mayer A and Höckel M: Tumor hypoxia and malignant progression. Methods Enzymol 381: 335-354, 2004.

123.Zeng W, Liu P, Pan W, Singh SR and Wei Y: Hypoxia and hypoxia inducible factors in tumor metabolism. Cancer Lett 356: 263-267, 2015

124. Korkolopoulou P,Patsouris E, Konstantinidou AE, Pavlopoulos PM, Kavantzas N, Boviatsis E, Thymara I, Perdiki M, Thomas-Tsagli E, Angelidakis D, et al: Hypoxia-inducible factor 1alpha/vascular endothelial growth factor axis in astrocytomas. Associations with microvessel morphometry, proliferation and prognosis. Neuropathol Appl Neurobiol 30: 267-278, 2004.

125. Mashiko R, Takano S, Ishikawa E, Yamamoto T, Nakai K and Matsumura A: Hypoxia-inducible factor $1 \alpha$ expression is a prognostic biomarker in patients with astrocytic tumors associated with necrosis on MR image. J Neurooncol 102: 43-50, 2011.

126. Søndergaard KL, Hilton DA, Penney M, Ollerenshaw M and Demaine AG: Expression of hypoxia-inducible factor 1alpha in tumours of patients with glioblastoma. Neuropathol Appl Neurobiol 28: 210-217, 2002

127. Bao L, Chen Y, Lai HT, Wu SY, Wang JE, Hatanpaa KJ, Raisanen JM,Fontenot M, Lega B, Chiang CM, et al: Methylation of hypoxia-inducible factor (HIF)- $1 \alpha$ by G9a/GLP inhibits HIF-1 transcriptional activity and cell migration. Nucleic Acids Res 46: 6576-6591, 2018.

128. Campbell EJ, Dachs GU, Morrin HR, Davey VC, Robinson BA and Vissers MCM: Activation of the hypoxia pathway in breast cancer tissue and patient survival are inversely associated with tumor ascorbate levels. BMC Cancer 19: 307, 2019.

129. Camarena V and Wang G: The epigenetic role of vitamin $C$ in health and disease. Cell Mol Life Sci 73: 1645-1658, 2016.

130. Satheesh NJ, Samuel SM and Büsselberg D: Combination therapy with vitamin c could eradicate cancer stem cells. Biomolecules 10: 79, 2020.

131. O'Leary BR, Houwen FK, Johnson CL, Allen BG, Mezhir JJ, Berg DJ, Cullen JJ and Spitz DR: Pharmacological ascorbate as an adjuvant for enhancing radiation-chemotherapy responses in gastric adenocarcinoma. Radiat Res 189: 456-465, 2018.

132. Espey MG, Chen P, Chalmers B, Drisko J, Sun AY, Levine M and Chen Q: Pharmacologic ascorbate synergizes with gemcitabine in preclinical models of pancreatic cancer. Free Radic Biol Med 50: 1610-1619, 2011

133. Moser JC, Rawal M, Wagner BA, Du J, Cullen JJ and Buettner GR: Pharmacological ascorbate and ionizing radiation (IR) increase labile iron in pancreatic cancer. Redox Biol 2: 22-27, 2013.

134. Chen Q, Espey MG, Sun AY, Pooput C, Kirk KL, Krishna MC, Khosh DB, Drisko J and Levine M: Pharmacologic doses of ascorbate act as a prooxidant and decrease growth of aggressive tumor xenografts in mice. Proc Natl Acad Sci USA 105: 11105-11109, 2008

135. Lu YX, Wu QN, Chen DL, Chen LZ, Wang ZX, Ren C, Mo HY, Chen Y, Sheng H, Wang YN, et al: Pharmacological ascorbate suppresses growth of gastric cancer cells with GLUT1 overexpression and enhances the efficacy of oxaliplatin through redox modulation. Theranostics 8: 1312-1326, 2018.

136. Oka N, Komuro A, Amano H, Dash S, Honda M, Ota K, Nishimura S, Ueda T, Akagi M and Okada H: Ascorbate sensitizes human osteosarcoma cells to the cytostatic effects of cisplatin. Pharmacol Res Perspect 8: e00632, 2020.

137. Kanter $\mathrm{M}$ and Akpolat $\mathrm{M}$ : Vitamin $\mathrm{C}$ protects against ionizing radiation damage to goblet cells of the ileum in rats. Acta Histochem 110: 481-490, 2008.

138. Ito Y, Kinoshita M, Yamamoto T, Sato T, Obara T, Saitoh D, Seki $S$ and Takahashi Y: A combination of pre- and post-exposure ascorbic acid rescues mice from radiation-induced lethal gastrointestinal damage. Int J Mol Sci 14: 19618-19635, 2013.

139. Vollbracht C, Schneider B, Leendert V, Weiss G, Auerbach L and Beuth $\mathrm{J}$ : Intravenous vitamin $\mathrm{C}$ administration improves quality of life in breast cancer patients during chemo-/radiotherapy and aftercare: Results of a retrospective, multicentre, epidemiological cohort study in Germany. In Vivo 25: 983-990, 2011

140. Polireddy K, Dong R, Reed G, Yu J, Chen P, Williamson S, Violet PC, Pessetto Z, Godwin AK, Fan F, et al: High dose parenteral ascorbate inhibited pancreatic cancer growth and metastasis: Mechanisms and a phase I/IIa study. Sci Rep 7: 17188,2017 
141. Nauman G, Gray JC, Parkinson R, Levine M and Paller CJ: Systematic review of intravenous ascorbate in cancer clinical trials. Antioxidants (Basel) 7: 89, 2018

142. Nielsen TK, Højgaard M, Andersen JT, Jørgensen NR, Zerahn B, Kristensen B, Henriksen T, Lykkesfeldt J, Mikines KJ and Poulsen HE: Weekly ascorbic acid infusion in castration-resistant prostate cancer patients: A single-arm phase II trial. Transl Androl Urol 6: 517-528, 2017.

143. Wang F, He MM, Wang ZX, Li S, Jin Y, Ren C, Shi SM, Bi BT, Chen SZ, Lv ZD, et al: Phase I study of high-dose ascorbic acid with mFOLFOX6 or FOLFIRI in patients with metastatic colorectal cancer or gastric cancer. BMC Cancer 19: 460, 2019.

144. Alexander MS, Wilkes JG, Schroeder SR, Buettner GR, Wagner BA, Du J, Gibson-Corley K, O'Leary BR, Spitz DR, Buatti JM, et al: Pharmacologic ascorbate reduces radiation-induced normal tissue toxicity and enhances tumor radiosensitization in pancreatic cancer. Cancer Res 78: 6838-6851, 2018.

145. Ou J, Zhu X, Chen P, Du Y, Lu Y, Peng X, Bao S, Wang J, Zhang $X$, Zhang $T$ and Pang CLK: A randomized phase II trial of best supportive care with or without hyperthermia and vitamin $\mathrm{C}$ for heavily pretreated, advanced, refractory non-small-cell lung cancer. J Adv Res 24: 175-182, 2020.

146. Allen BG, Bodeker KL, Smith MC, Monga V, Sandhu S, Hohl R, Carlisle T, Brown H, Hollenbeck N, Vollstedt S, et al: First-in-human phase I clinical trial of pharmacologic ascorbate combined with radiation and temozolomide for newly diagnosed glioblastoma. Clin Cancer Res 25: 6590-6597, 2019.

147. Baillie N, Carr AC and Peng S: The use of intravenous vitamin C as a supportive therapy for a patient with glioblastoma multiforme. Antioxidants (Basel) 7: 115, 2018

148. Cushing CM, Petronek MS, Bodeker KL, Vollstedt S, Brown HA Opat E, Hollenbeck NJ, Shanks T, Berg DJ, Smith BJ, et al: Magnetic resonance imaging (MRI) of pharmacological ascorbate-induced iron redox state as a biomarker in subjects undergoing radio-chemotherapy. Redox Biol 38: 101804, 2021.

149. Padayatty SJ, Sun H, Wang Y, Riordan HD, Hewitt SM, Katz A, Wesley RA and Levine M: Vitamin C pharmacokinetics: Implications for oral and intravenous use. Ann Intern Med 140: 533-537, 2004.

150. Fowler AA III, Syed AA, Knowlson S, Sculthorpe R, Farthing D, DeWilde C, Farthing CA, Larus TL, Martin E, Brophy DF, et al Phase I safety trial of intravenous ascorbic acid in patients with severe sepsis. J Transl Med 12: 32, 2014.

151. Zabet MH, Mohammadi M, Ramezani M and Khalili H: Effect of high-dose ascorbic acid on vasopressor's requirement in septic shock. J Res Pharm Pract 5: 94-100, 2016.

152. Tanaka H, Matsuda T, Miyagantani Y, Yukioka T, Matsuda $H$ and Shimazaki S: Reduction of resuscitation fluid volumes in severely burned patients using ascorbic acid administration: A randomized, prospective study. Arch Surg 135: 326-331, 2000.

153. Li G, Qin Z, Chen Z, Xie L, Wang R and Zhao H: Tumor microenvironment in treatment of glioma. Open Med (Wars) 12 247-251, 2017.

154. Ginhoux F, Greter M, Leboeuf M, Nandi S, See P, Gokhan S, Mehler MF, Conway SJ, Ng LG, Stanley ER, et al: Fate mapping analysis reveals that adult microglia derive from primitive macrophages. Science 330: 841-845, 2010.

155. Charles NA, Holland EC, Gilbertson R, Glass R and Kettenmann H: The brain tumor microenvironment. Glia 60 502-514, 2012.

156. Poon CC, Sarkar S, Yong VW and Kelly JJP: Glioblastomaassociated microglia and macrophages: Targets for therapies to improve prognosis. Brain 140: 1548-1560, 2017.

157. Poon CC, Gordon PMK, Liu K, Yang R, Sarkar S, Mirzaei R, Ahmad ST, Hughes ML, Yong VW and Kelly JJP: Differential microglia and macrophage profiles in human IDH-mutant and -wild type glioblastoma. Oncotarget 10: 3129-3143, 2019.

158. Tomaszewski W, Sanchez-Perez L, Gajewski TF and Sampson JH Brain tumor microenvironment and host state: Implications for immunotherapy. Clin Cancer Res 25: 4202-4210, 2019.

159. Hwang SY, Yoo BC, Jung J, Oh ES, Hwang JS, Shin JA, Kim SY, Cha SH and Han IO: Induction of glioma apoptosis by microglia-secreted molecules: The role of nitric oxide and cathepsin B. Biochim Biophys Acta 1793: 1656-1668, 2009.

160. Chicoine MR, Zahner M, Won EK, Kalra RR, Kitamura T, Perry A and Higashikubo R: The in vivo antitumoral effects of lipopolysaccharide against glioblastoma multiforme are mediated in part by Toll-like receptor 4. Neurosurgery 60: 372-381, 2007.
161. Martins TA, Schmassmann P, Shekarian T, Boulay JL, Ritz MF, Zanganeh S, vom Berg J and Hutter G: Microglia-centered combinatorial strategies against glioblastoma. Front Immunol 11: 571951, 2020

162. Gupta K and Burns TC: Radiation-induced alterations in the recurrent glioblastoma microenvironment: Therapeutic implications. Front Oncol 8: 503, 2018.

163. Yoshimura M, Itasaka S, Harada $H$ and Hiraoka M: Microenvironment and radiation therapy. Biomed Res Int 2013: 685308, 2013

164. Bellail AC, Hunter SB, Brat DJ, Tan C and van Meir EG: Microregional extracellular matrix heterogeneity in brain modulates glioma cell invasion. Int J Biochem Cell Biol 36 1046-1069, 2004

165. Wild-Bode C, Weller M, Rimner A, Dichgans J and Wick W Sublethal irradiation promotes migration and invasiveness of glioma cells: Implications for radiotherapy of human glioblastoma. Cancer Res 61: 2744-2750, 2001.

166. Shankar A, Kumar S, Iskander AS, Varma NR, Janic B, deCarvalho A, Mikkelsen T, Frank JA, Ali MM, Knight RA, et al Subcurative radiation significantly increases cell proliferation, invasion, and migration of primary glioblastoma multiforme in vivo. Chin J Cancer 33: 148-158, 2014.

167. Wank M, Schilling D, Reindl J, Meyer B, Gempt J, Motov S, Alexander F, Wilkens JJ, Schlegel J, Schmid TE and Combs SE: Evaluation of radiation-related invasion in primary patient-derived glioma cells and validation with established cell lines: Impact of different radiation qualities with differing LET. J Neurooncol 139: 583-590, 2018

168. Wank M, Schilling D, Schmid TE, Meyer B, Gempt J, Barz M, Schlegel J, Liesche F, Kessel KA, Wiestler B, et al: Human glioma migration and infiltration properties as a target for personalized radiation medicine. Cancers (Basel) 10: 456 , 2018.

169. Zhang X, Wang X, Xu R, Ji J, Xu Y, Han M, Wei Y, Huang B, Chen A, Zhang Q, et al: YM155 decreases radiation-induced invasion and reverses epithelial-mesenchymal transition by targeting STAT3 in glioblastoma. J Transl Med 16: 79, 2018.

170. Gupta K, Vuckovic I, Zhang S, Xiong Y, Carlson BL, Jacobs J, Olson I, Petterson XM, Macura SI, Sarkaria J and Burns TC: Radiation induced metabolic alterations associate with tumor aggressiveness and poor outcome in glioblastoma. Front Oncol 10: 535, 2020.

171. Dixit S, Bernardo A, Walker JM, Kennard JA, Kim GY, Kessler ES and Harrison FE: Vitamin C deficiency in the brain impairs cognition, increases amyloid accumulation and deposition, and oxidative stress in APP/PSEN1 and normally aging mice. ACS Chem Neurosci 6: 570-581, 2015.

172. Portugal CC, Socodato R and Relvas JB: The ascorbate transporter SVCT2 to target microglia-dependent inflammation. Oncotarget 8: 99217-99218, 2017.

173. Azzolini C, Fiorani M, Cerioni L, Guidarelli A and Cantoni O: Sodium-dependent transport of ascorbic acid in U937 cell mitochondria. IUBMB Life 65: 149-153, 2013.

174. Muñoz-Montesino C, Roa FJ, Peña E, González M, Sotomayor K Inostroza E, Muñoz CA, González I, Maldonado M, Soliz C, et al: Mitochondrial ascorbic acid transport is mediated by a low-affinity form of the sodium-coupled ascorbic acid transporter-2. Free Radic Biol Med 70: 241-254, 2014

175. Peña E, Roa FJ, Inostroza E, Sotomayor K, González M, Gutierrez-Castro FA, Maurin M, Sweet K, Labrousse C, Gatica $\mathrm{M}$, et al: Increased expression of mitochondrial sodium-coupled ascorbic acid transporter-2 (mitSVCT2) as a central feature in breast cancer. Free Radic Biol Med 135 283-292, 2019.

176. Roa FJ, Peña E, Gatica M, Escobar-Acuña K, Saavedra P, Maldonado M, Cuevas ME, Moraga-Cid G, Rivas CI and Muñoz-Montesino C: Therapeutic use of vitamin $\mathrm{C}$ in cancer: Physiological considerations. Front Pharmacol 11: 211, 2020.

177. McCaffrey G, Staatz WD, Quigley CA, Nametz N, Seelbach MJ, Campos CR, Brooks TA, Egleton RD and Davis TP: Tight junctions contain oligomeric protein assembly critical for maintaining blood-brain barrier integrity in vivo. J Neurochem 103 2540-2555, 2007.

178. Kook SY, Lee KM, Kim Y, Cha MY, Kang S, Baik SH, Lee H, Park R and Mook-Jung I: High-dose of vitamin C supplementation reduces amyloid plaque burden and ameliorates pathological changes in the brain of 5XFAD mice. Cell Death Dis 5: e1083, 2014 . 
179. Dubois LG, Campanati L, Righy C, D'Andrea-Meira I, Spohr TC, Porto-Carreiro I, Pereira CM, Balça-Silva J, Kahn SA, DosSantos MF, et al: Gliomas and the vascular fragility of the blood brain barrier. Front Cell Neurosci 8: 418, 2014.

180. Prata C, Hrelia S and Fiorentini D: Peroxiporins in cancer. Int J Mol Sci 20: 1371, 2019.

181. Henzler T and Steudle E: Transport and metabolic degradation of hydrogen peroxide in Chara corallina: Model calculations and measurements with the pressure probe suggest transport of $\mathrm{H}(2) \mathrm{O}(2)$ across water channels. J Exp Bot 51: 2053-2066, 2000

182. Noell S, Ritz R, Wolburg-Buchholz K, Wolburg H and Fallier-Becker P: An allograft glioma model reveals the dependence of aquaporin-4 expression on the brain microenvironment. PLoS One 7: e36555, 2012.

183. Warth A, Kröger S and Wolburg H: Redistribution of aquaporin-4 in human glioblastoma correlates with loss of agrin immunoreactivity from brain capillary basal laminae. Acta Neuropathol 107: 311-318, 2004.

184. Markert JM, Fuller CM, Gillespie GY, Bubien JK, McLean LA Hong RL, Lee K, Gullans SR, Mapstone TB and Benos DJ: Differential gene expression profiling in human brain tumors. Physiol Genomics 5: 21-33, 2001.

185. Papadopoulos MC and Saadoun S: Key roles of aquaporins in tumor biology. Biochim Biophys Acta 1848: 2576-2583, 2015.

186. Labak CM, Wang PY, Arora R, Guda MR, Asuthkar S, Tsung AJ and Velpula KK: Glucose transport: Meeting the metabolic demands of cancer, and applications in glioblastoma treatment Am J Cancer Res 6: 1599-1608, 2016.

187. Castro MA, Pozo M, Cortés C, García Mde L, Concha II and Nualart F: Intracellular ascorbic acid inhibits transport of glucose by neurons, but not by astrocytes. J Neurochem 102: 773-782, 2007.

188. Azzalin A, Nato G, Parmigiani E, Garello F, Buffo A and Magrassi L: Inhibitors of GLUT/SLC2A enhance the action of BCNU and temozolomide against high-grade gliomas. Neoplasia 19: 364-373, 2017.

189. Astuya A, Caprile T, Castro M, Salazar K, García Mde L, Reinicke K, Rodríguez F, Vera JC, Millán C, Ulloa V, et al: Vitamin $\mathrm{C}$ uptake and recycling among normal and tumor cells from the central nervous system. J Neurosci Res 79: 146-156, 2005.

190. Chen S, Roffey DM, Dion CA, Arab A and Wai EK: Effect of perioperative vitamin $C$ supplementation on postoperative pain and the incidence of chronic regional pain syndrome: A systematic review and meta-analysis. Clin J Pain 32: 179-185, 2016.

191. Salazar K, Martínez F, Pérez-Martín M, Cifuentes M, Trigueros L, Ferrada L, Espinoza F, Saldivia N, Bertinat R, Forman K, et al: SVCT2 expression and function in reactive astrocytes is a common event in different brain pathologies. Mol Neurobiol 55: 5439-5452, 2018.

192. Heneka MT, Carson MJ, El Khoury J, Landreth GE, Brosseron F, Feinstein DL, Jacobs AH, Wyss-Coray T, Vitorica J, Ransohoff RM, et al: Neuroinflammation in Alzheimer's disease. Lancet Neurol 14: 388-405, 2015.

193. Berger UV, Lu XC, Liu W, Tang Z, Slusher BS and Hediger MA Effect of middle cerebral artery occlusion on mRNA expression for the sodium-coupled vitamin C transporter SVCT2 in rat brain. J Neurochem 86: 896-906, 2003.

194. Savini I, Rossi A, Catani MV, Ceci R and Avigliano L: Redox regulation of vitamin C transporter SVCT2 in C2C12 myotubes. Biochem Biophys Res Commun 361: 385-390, 2007.

195. Reuter S, Gupta SC, Chaturvedi MM and Aggarwal BB: Oxidative stress, inflammation, and cancer: How are they linked? Free Radic Biol Med 49: 1603-1616, 2010.
196. Harris HR, Orsini N and Wolk A: Vitamin C and survival among women with breast cancer: A meta-analysis. Eur J Cancer 50 1223-1231, 2014.

197. Wilson MK, Baguley BC, Wall C, Jameson MB and Findlay MP: Review of high-dose intravenous vitamin $\mathrm{C}$ as an anticancer agent. Asia Pac J Clin Oncol 10: 22-37, 2014.

198. Hunnisett A, Davies S, McLaren-Howard J, Gravett P, Finn M and Gueret-Wardle D: Lipoperoxides as an index of free radical activity in bone marrow transplant recipients. Preliminary observations. Biol Trace Elem Res 47: 125-132, 1995.

199. Nan-Ya K, Kajihara M, Kojima N and Degawa M: Usefulness of urinary kidney injury molecule-1 (Kim-1) as a biomarker for cisplatin-induced sub-chronic kidney injury. J Appl Toxicol 35 124-132, 2015

200. Schoenfeld JD, Sibenaller ZA, Mapuskar KA, Wagner BA, Cramer-Morales KL, Furqan M, Sandhu S, Carlisle TL, Smith MC, Abu Hejleh T, et al: $\mathrm{O}_{2}^{-}$and $\mathrm{H}_{2} \mathrm{O}_{2}$-mediated disruption of fe metabolism causes the differential susceptibility of NSCLC and GBM cancer cells to pharmacological ascorbate. Cancer Cell 31: 487-500.e8, 2017.

201. Attia M, Essa EA, Zaki RM and Elkordy AA: An overview of the antioxidant effects of ascorbic acid and alpha lipoic acid (in liposomal forms) as adjuvant in cancer treatment. Antioxidants (Basel) 9: 359, 2020.

202. Milletti F: Cell-penetrating peptides: Classes, origin, and current landscape. Drug Discov Today 17: 850-860, 2012.

203. Hultqvist G, Syvänen S, Fang XT, Lannfelt L and Sehlin D: Bivalent brain shuttle increases antibody uptake by monovalent binding to the transferrin receptor. Theranostics 7: 308-318, 2017

204. Staquicini FI, Ozawa MG, Moya CA, Driessen WH, Barbu EM, Nishimori H, Soghomonyan S, Flores LG II, Liang X, Paolillo V, et al: Systemic combinatorial peptide selection yields a non-canonical iron-mimicry mechanism for targeting tumors in a mouse model of human glioblastoma. J Clin Invest 121: $161-173,2011$

205. Tong HI, Kang W, Davy PM, Shi Y, Sun S, Allsopp RC and Lu Y: Monocyte trafficking, engraftment, and delivery of nanoparticles and an exogenous gene into the acutely inflamed brain tissue-evaluations on monocyte-based delivery system for the central nervous system. PLoS One 11: e0154022, 2016.

206. Di Tacchio M, Macas J, Weissenberger J, Sommer K, Bähr O, Steinbach JP, Senft C, Seifert V, Glas M, Herrlinger U, et al: Tumor vessel normalization, immunostimulatory reprogramming, and improved survival in glioblastoma with combined inhibition of PD-1, angiopoietin-2, and VEGF. Cancer Immunol Res 7: 1910-1927, 2019.

207. Przystal JM, Waramit S, Pranjol MZI, Yan W, Chu G, Chongchai A, Samarth G, Olaciregui NG, Tabatabai G, Carcaboso AM, et al: Efficacy of systemic temozolomide-activated phage-targeted gene therapy in human glioblastoma. EMBO Mol Med 11: e8492, 2019.

208. Carr A, Wohlrab C, Young P and Bellomo R: Stability of intravenous vitamin $\mathrm{C}$ solutions: A technical report. Crit Care Resusc 20: 180-181, 2018.

This work is licensed under a Creative Commons Attribution-NonCommercial-NoDerivatives 4.0 International (CC BY-NC-ND 4.0) License. 